\title{
Update on psoriasis immunopathogenesis and targeted immunotherapy
}

\author{
Satveer K. Mahil ${ }^{1}$ - Francesca Capon ${ }^{2}$. Jonathan N. Barker ${ }^{1}$
}

Received: 26 June 2015 / Accepted: 30 October 2015 / Published online: 16 November 2015

(C) The Author(s) 2015. This article is published with open access at Springerlink.com

\begin{abstract}
Over recent years, significant progress has been made in characterisation of the underlying pathogenic mechanisms in psoriasis, a common cutaneous disease that is associated with major systemic co-morbidity and reduced life expectancy. Basic science discoveries have informed the design of novel therapeutic approaches, many of which are now under evaluation in late-stage clinical trials. Here we describe the complex interplay between immune cell types and cytokine networks that acts within self-perpetuating feedback loops to drive cutaneous inflammation in psoriasis. Genetic studies have been pivotal in the construction of the disease model and more recently have uncovered a distinct aetiology for rare, pustular variants of psoriasis. The translation of mechanistic insights into potential advancements in clinical care will also be described, including several treatments that target the interleukin-23 (IL-23)/T17 immune axis.
\end{abstract}

This article is a contribution to the Special Issue on Immunodermatology - Guest Editors: Lars French and Alexander Navarin

Jonathan N. Barker

jonathan.barker@kcl.ac.uk

1 St John's Institute of Dermatology, Division of Genetics and Molecular Medicine, King's College London, London, UK

2 Department of Medical and Molecular Genetics, Division of Genetics and Molecular Medicine, King's College London, London, UK

\section{Introduction}

The therapeutic armamentarium for psoriasis has expanded over the past two decades with the development of several highly selective therapies that are both efficacious and have a favourable safety profile. Novel insights into psoriasis immunopathogenesis have informed the design of these treatments, and in turn, mechanistic studies within clinical trials are helping to further characterise the role of different cellular players and cytokine axes in the pathogenic disease model.

Psoriasis is a phenotypically heterogeneous, immunemediated skin condition that often follows a relapsing and remitting course. It is a common, complex trait that affects approximately $2 \%$ of the general population and is associated with multiple co-morbidities including arthritis, cardiovascular disease, obesity, hypertension, diabetes mellitus, reduced quality of life and depression [1-4]. Almost $90 \%$ of individuals have psoriasis vulgaris and the majority of research to date (as described in this review) has investigated this form of the disease. It is characterised by well-demarcated, scaling, erythematous plaques that frequently manifest at sites of trauma (extensor aspects of elbows, knees), however can appear anywhere on the body. Approximately one third of patients have moderate to severe disease, which affects more than $10 \%$ of body surface area, and usually necessitates systemic medications. Other clinical variants include pustular psoriasis, guttate psoriasis and erythroderma. Emerging evidence indicates that the distinct phenotypes have different immunogenetic profiles, which will likely influence treatment choices [5]. Discoveries from genetics and immunology research have converged to shape the current pathogenic model for psoriasis. In particular, hypothesis-free large-scale case-control genetic analyses such as genome-wide association studies (GWAS) have highlighted key roles for the regulation of specific innate and adaptive immune pathways, such as antiviral responses 
and the IL-23/T17 axis, respectively, which have been substantiated by immunological data [6].

\section{Pathogenic model for psoriasis}

The pathogenesis of psoriasis involves dynamic interactions between multiple cell types and numerous cytokines in response to triggers, culminating in the disruption of skin immune homeostasis in genetically predisposed individuals. The histological features of a psoriatic plaque provide an insight into the immunological complexities of the disease. There is thickening of the epidermis (acanthosis) due to an increase in keratinocyte turnover [7]. The retention of keratinocyte nuclei in the stratum corneum (parakeratosis) due to abnormal differentiation further highlights the importance of these skin cells in the development of psoriasis. Psoriatic lesions are also densely infiltrated by $\mathrm{T}$ cells and dendritic cells (DC). These immune effectors produce pro-inflammatory cytokines such as tumour necrosis factor $\alpha(\mathrm{TNF} \alpha)$, interferon $\gamma(\mathrm{IFN} \gamma)$, interleukin-17 (IL-17), IL-22, IL-23 and IL-1 $\beta$. Neutrophils collect in the epidermis and form collections called Munro's microabscesses. Plaques are highly vascular and new vessel formation is mediated by angiogenic factors such as vascular endothelial growth factor (VEGF).

The initiation phase of a psoriatic lesion involves a close interplay between external factors and genetic alterations that predispose to the phenotype [3]. Triggers include physical injury (which causes Koebner phenomenon), infections (particularly streptococcal) and medications (e.g. $\beta$-blockers, lithium). Although the exact mechanisms for the induction of psoriasis are not yet fully elucidated for many of these environmental factors, some insults such as physical trauma cause the release of the antimicrobial peptide LL37 (cathelicidin) by keratinocytes, which then mediates the breakdown of tolerance to self-nucleic acids (Fig. 1). LL37 binds with pathogen-derived DNA or self-DNA that has been released by stressed or dying cells and forms complexes that activate Toll-like receptor 9 (TLR9) on plasmacytoid DCs [8, 9]. This promotes type I IFN release, which, along with TNF $\alpha$, IL-6 and IL-1 $\beta$, activates local myeloid DCs, thus promoting T cell-mediated inflammation. There is also evidence that LL37 may directly activate auto-reactive circulating T cells, and this phenomenon was more prevalent in psoriasis patients with greater disease activity [10].

Myeloid DCs migrate into draining lymph nodes and release cytokines including TNF $\alpha$, IL-23 and IL-12 that activate allogeneic T cells (Fig. 2). Once activated, T cells enter the circulation and move towards inflamed skin through interactions with adhesion molecules (including P-selectin and Eselectin) on the endothelial cells of blood vessels. The effector molecules secreted by $\mathrm{T}$ cells then activate keratinocytes, resulting in the release of cytokines and chemokines that continue to recruit and activate inflammatory cells. For example, IFN $\gamma$, IL-17 and IL-22 are secreted by T helper type 1 (Th1), Th17 and Th22 cells, respectively, which contribute to the amplification of cutaneous inflammation.

LL37 may also bind to self-RNA and directly activate myeloid DCs via TLR7 and TLR8 [11]. This results in the upregulation of TNF $\alpha$ and IL-6. In support of this disease initiation model, the TLR7/8 agonist imiquimod has been shown to induce psoriasiform skin inflammation in mouse models [12]. These changes were blocked in mice deficient for the IL-23 or IL-17 receptor, which indicates a role for crosstalk between keratinocytes and the IL-23/T17 pathway in the pathogenesis of psoriasis.

The following sections summarise the roles of specific cells and cytokines in initiating and maintaining the dysregulated immune response that leads to psoriasis. An update on the therapeutic agents currently available and in clinical trial stage is also included.

\section{The role of immune cell types in psoriasis}

\section{Dendritic cells}

DCs are professional antigen presenting cells that activate T cells and are an important source of pro-inflammatory cytokines and chemokines in psoriasis. Genetic studies indicate a fundamental role for antigen presentation in the disease process since the PSORS1 interval on chromosome 6p21.3 confers the greatest risk and is the most replicated locus for psoriasis [13-15]. The likely causal allele within PSORS1 is $H L A-C w 6$, which encodes a class I major histocompatibility complex (MHC) molecule that is expressed by antigen presenting cells and mediates T cell activation [16, 17]. It is estimated to account for approximately $50 \%$ of disease heritability and the odds ratios observed in GWAS have ranged between 2.6 and 4.7 [18-21]. Genetic variants within ERAP1 interact with $H L A-C w 6$ (genetic epistasis), such that ERAPI risk alleles are only associated with psoriasis susceptibility in individuals harbouring $H L A-C w 6$ [19]. The protein product of ERAP1 trims peptides to enable effective loading onto MHC class I molecules, thus reinforcing the role for antigen presentation and subsequent abnormal $\mathrm{T}$ cell activation in the disease model.

The main lineages of DCs that have been characterised in psoriasis are plasmacytoid DCs and myeloid DCs. They localise to the dermis and express distinct cell surface markers. The $\alpha_{\mathrm{x}}$ integrin CD11c is a marker of myeloid DCs, which are considered to be important in the early stages of disease. The blood DC antigens (BDCA) identify different subsets of myeloid DCs, such as BDCA-1+ 'resident' DCs and BDCA-1'inflammatory' DCs. The latter have been found in greater numbers in the dermis of lesional psoriatic skin compared 


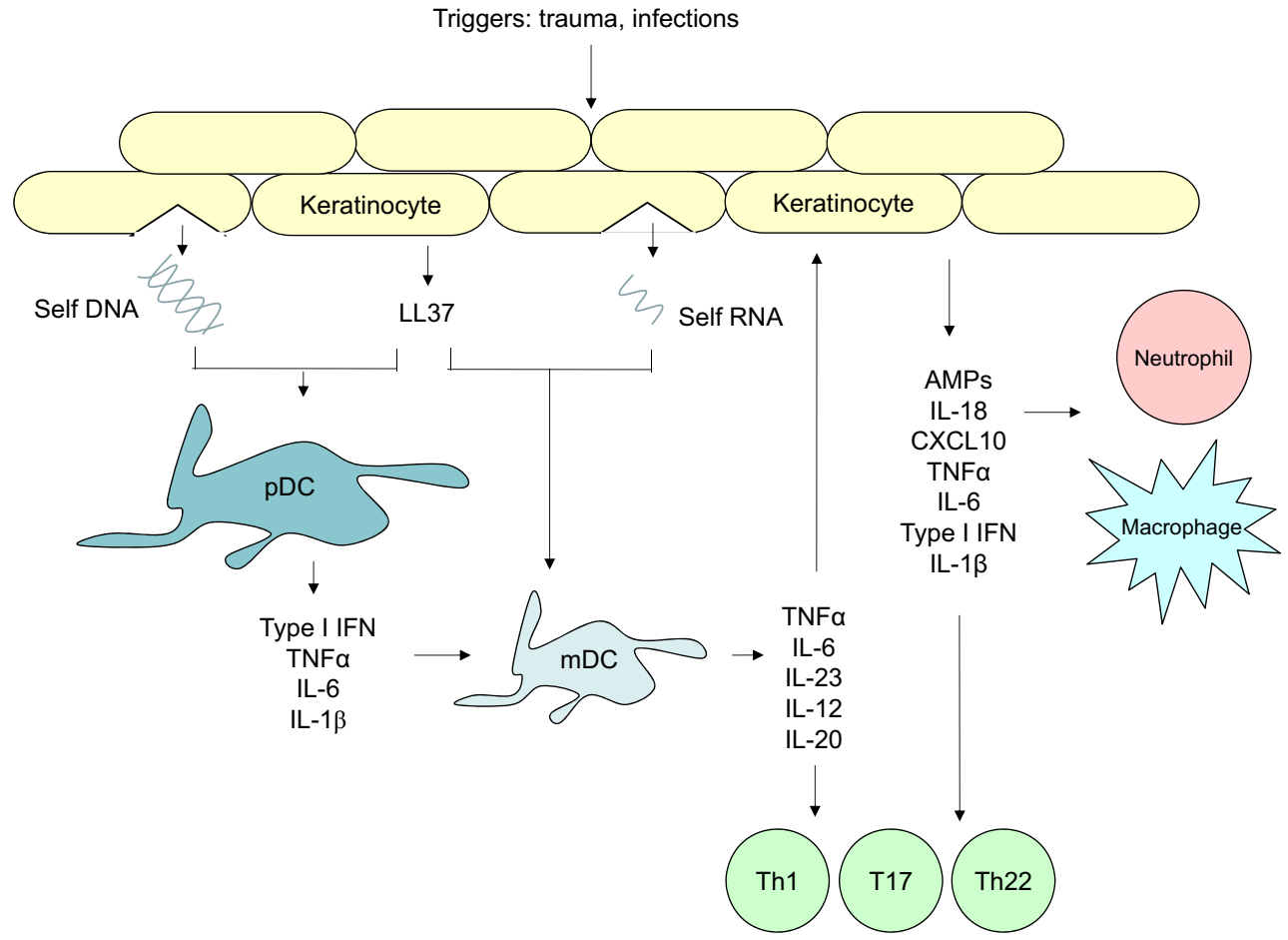

Fig. 1 Schema for the initiation of a psoriatic skin lesion. Triggers such as trauma and infections lead to the release of self-DNA and self-RNA, which form complexes with LL37 and activate plasmacytoid dendritic cells (pDCs) and myeloid dendritic cells (mDCs), respectively. pDCs secrete type I interferons (IFN) and other cytokines including TNF $\alpha$, IL- 6 and IL- $1 \beta$, which promote the activation of mDCs. These antigen presenting cells release pro-inflammatory cytokines that drive $\mathrm{T}$ cellmediated inflammation and keratinocyte activation and proliferation. This promotes the recruitment and activation of further inflammatory cells such as neutrophils and macrophages, contributing to the formation of an inflamed cutaneous plaque. AMPs antimicrobial peptides

Plasmacytoid DCs are a rich source of type I IFN, an early signature cytokine in psoriasis, and have been found at with non-lesional or normal skin [22-24] and decrease in number following effective psoriasis treatment [24, 25].

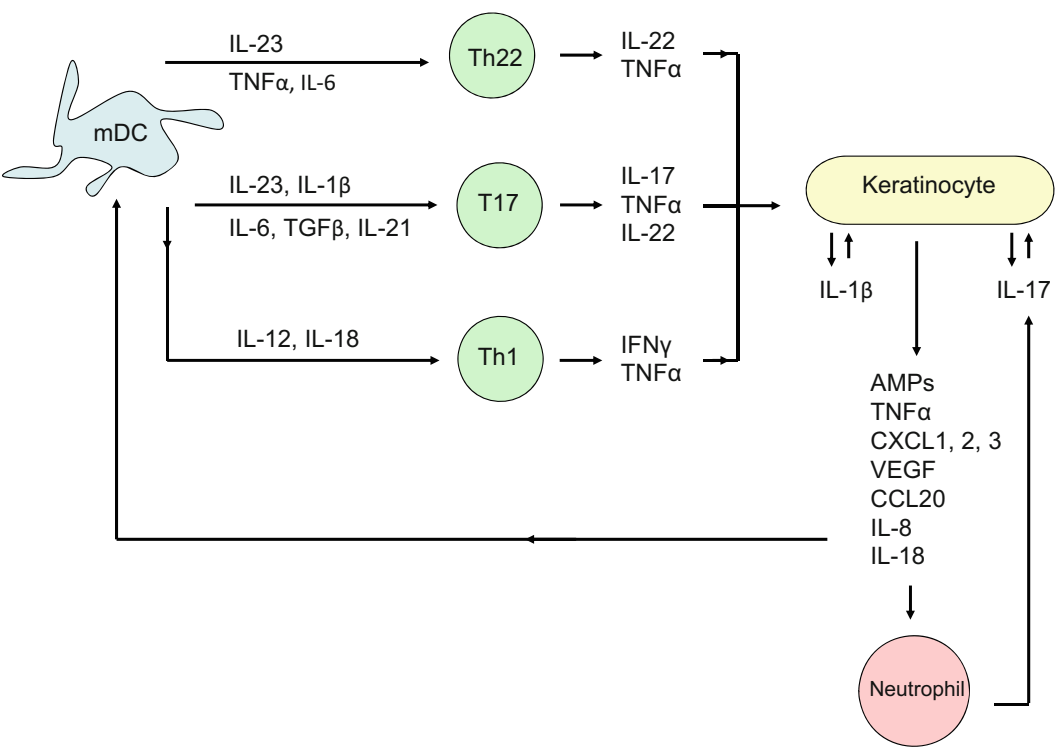

Fig. 2 Schema of the contribution of T cell subsets to the pathogenesis of psoriasis. Activated myeloid dendritic cells $(\mathrm{mDC})$ release cytokines that promote the differentiation of populations of resident $\mathrm{T}$ cells into $\mathrm{Th} 22$, $\mathrm{T} 17$ and Th1 cells. Cytokines secreted by these effector T cells stimulate keratinocytes, which promote the recruitment of other inflammatory cells such as neutrophils by release of chemokines. Activation of autocrine and paracrine feedback loops culminates in the development and maintenance of cutaneous inflammation. AMPs antimicrobial peptides, VEGF vascular endothelial growth factor 
increased levels in lesional skin compared with normal skin [26-28]. Plasmacytoid DCs help to initiate disease and are activated by LL37/DNA complexes, as described above. The importance of this cell type in the disease model has been supported by xenotransplantation models of psoriasis, in which non-lesional skin from patients with psoriasis are grafted onto athymic nude mice (deficient in T cells) or those with severe combined immunodeficiency (without $\mathrm{T}$ and $\mathrm{B}$ cells) [29]. In these experimental systems, inhibition of type I IFN release or signalling by plasmacytoid DC blocked pathogenic $\mathrm{T}$ cell activation, which prevented the development of psoriasis $[15,16]$.

Langerhans cells are skin-resident immune cells that associate closely with keratinocytes in the epidermis via Ecadherin. Although Langerhans cells are able to present antigens to T cells in local skin-draining lymph nodes, their role in disease pathogenesis and the nature of the putative psoriasis antigen remains unclear. Previous studies have shown that Langerhans cell migration in non-lesional skin is impaired in early-onset (before age 40; type I) psoriasis [30, 31] and restored with anti-psoriatic biologic treatments [32]. This suggests that loss of cell mobility may cause a dysregulated cutaneous immune response.

\section{Keratinocytes}

Keratinocytes are believed to be crucial in both the early stages of disease pathogenesis and later amplification of chronic inflammatory circuits. As the major constituent of the epidermis, keratinocytes have structural and immunological functions. They form the body's first line of defence against exogenous physical, chemical and microbial insults. Genetic studies indicate a role for skin barrier dysfunction in psoriasis since deletion of $L C E 3 B$ and $L C E 3 C$ genes, encoding stratum corneum proteins involved in terminal differentiation of the epidermis, was found to be associated with psoriasis [33]. It is hypothesised that incomplete repair after minor skin injury, due to $L C E$ gene deletion, contributes to the development of chronic inflammation [34].

Injury to the skin, resulting in cell death, causes the release of antimicrobial peptides (AMPs) by keratinocytes. AMPs, such as LL37, S100 proteins and $\beta$-defensins, are key mediators of the innate immune response and have been implicated in psoriasis pathogenesis. Specifically, genetic studies have demonstrated an association between increased $\beta$-defensin genomic copy number and risk of disease $[35,36]$. AMPs have been shown to be upregulated in psoriasis and its expression is reduced after successful treatment with systemic agents [37]. These molecules have direct antimicrobial activity and also help to modulate immune cells by promoting the upregulation of pro-inflammatory cytokines such as IL-6 and IL-10 and chemokines such as IL-8 (CXCL8) and CXCL10. This mediates the recruitment of macrophages and neutrophils.
In addition to being a rich source of AMPs, keratinocytes also release IL-1 family cytokines including IL-1 $\beta$ and IL-18, which help to initiate the cutaneous inflammatory response to injury. Keratinocytes contain inflammasomes, which are multi-protein complexes that consist of caspase-1, the adaptor protein ASC and a sensor protein (either a nod-like receptor e.g. NLRP3 or a pyrin and HIN domain protein e.g. AIM2), that detect sterile stressors and pathogens [38]. Activated caspase-1 cleaves pro-IL-1 and pro-IL-18 into the mature, active forms of the cytokines. IL- $1 \beta$ thus released has several paracrine effects including the production of TNF $\alpha$ by local keratinocytes and upregulation of leucocyte chemotactic proteins e.g. selectins, which promote the skin infiltration and activation of T cells. IL-18 and IL-1 $\beta$ are further involved in the differentiation of Th1 cells and Th17 cells, respectively (Fig. 2) $[39,40]$. This sets up positive feedback loops as activated Th1 and Th17 cells release IL-22 and IL-17 (Th17 only), which drives keratinocyte proliferation and activation, hence contributing to the formation of a cutaneous plaque. $\mathrm{T}$ cells also upregulate $\mathrm{S} 100$ proteins in keratinocytes, which in turn mediates further leucocyte chemotaxis.

Several genes expressed within keratinocytes that promote innate responses to viral nucleic acids and are upregulated in psoriatic skin lesions have been found by GWAS to confer disease susceptibility. The RIG-I and MDA5 innate antiviral receptors, encoded by the psoriasis-associated genes DDX58 and $I F I H 1$, respectively, bind to viral double-stranded RNA and promote the release of pro-inflammatory cytokines that have been implicated in psoriatic lesion initiation such as type I IFN, IL-1, IL-6, and IL-29 [19, 21, 41]. IL-29 signals through a receptor encoded by IL28RA, which has also been identified by GWAS [19]. The signalling cascade triggered by RIG-I and MDA5 is regulated by the protein product of the disease susceptibility gene RNF114 [42, 43]. Hence, dysregulated antiviral immunity may contribute to the development of psoriasis by promoting the over-production of proinflammatory cytokines by keratinocytes.

Keratinocytes also produce VEGF during inflammatory states, which induces angiogenesis by promoting the migration, survival and proliferation of endothelial cells, resulting in the formation of an erythematous, vascular plaque. In support, VEGF overexpression in mouse skin results in a psoriasiform phenotype [44].

\section{Neutrophils}

Neutrophils are important in the early stages of psoriasis as they are involved in the recruitment and activation of $\mathrm{T}$ cells and the proliferation and differentiation of keratinocytes [45]. Neutrophils are predominantly found in the epidermis in psoriasis and are recruited by the chemokines CXCL1, CXCL2, IL-8 and IL-18. Activated neutrophils release pro-inflammatory cytokines 
such as IL-17, AMPs and proteases. AMPs are released as neutrophil extracellular traps (NETs), which are weblike structures that are composed predominantly of neutrophil DNA. NETs have been shown to mediate autoimmune disease-associated organ damage [46] and have been identified in psoriatic lesions [47]. Elastase is a protease that is released by neutrophils in response to $\mathrm{TNF} \alpha$ or IL-8. It has several downstream effects, including the induction of keratinocyte proliferation and cleavage of cytokines into their active forms [48]. The importance of neutrophil-keratinocyte crosstalk in early psoriasis pathogenesis was highlighted by a recent report [49], in which the anti-IL-17A antibody secukinumab caused a rapid reduction in cutaneous neutrophils alongside histological improvement in keratinocyte abnormalities and downregulation of keratinocyte-derived neutrophil chemoattractants e.g. CXCL1.

\section{Macrophages}

The role of macrophages in psoriasis is not yet fully characterised; however, they are speculated to contribute to the disease as there is a threefold increase in cell numbers in lesional skin, with evidence of normalisation after successful treatment [24]. Mouse models with skin phenotypes that resemble human psoriasis support involvement from skin macrophages in disease development and maintenance [50, 51]. Cutaneous macrophages can be identified by their expression of CD163, and activated macrophages produce high levels of $\mathrm{TNF} \alpha$ and are likely to regulate angiogenesis via the release of VEGF [52].

\section{T cells}

The importance of abnormal T cell activation in the pathogenesis of psoriasis has been highlighted by several genetic studies that demonstrate a strong disease association with the HLA-Cw6 allele, as described above. GWAS have also identified multiple genes involved in the IL-23/T17 axis e.g. IL23R, IL23A and IL12B (Fig. 3) [18, 53], which emphasises this particular $\mathrm{T}$ cell subset as being crucial to the disease process. Further, a missense mutation (R381Q) in IL23R was shown to impair IL-23-induced Th17 activation and effector function and confer protection against psoriasis [54]. Hence, aberrant IL-23 signalling and Th17 activity contribute to chronic inflammation in psoriasis.

A key role for T cells is also indicated by their prevalence in lesional skin biopsies [55]. This is supported by the effectiveness of several $\mathrm{T}$ cell-directed therapies in causing disease resolution. The first successful drug was $\mathrm{DAB}_{389} \mathrm{IL}-2$, an IL2 fusion protein that causes apoptosis of activated T cells i.e. cells expressing functional IL-2 receptors [56]. The observed beneficial effects of other agents such as abatacept (CTLA-4Ig), which blocks T cell co-stimulation, and alefacept, an LFA3-Ig fusion protein that inhibits effector memory T cell activation, further re-enforced the important pathogenic activity of this cell type in psoriasis [57-59]. Clinical improvements with these agents were associated with a decrease in the number of T cells and DCs infiltrating skin lesions. Xenotransplantation mouse models provided additional evidence, since asymptomatic skin grafts developed typical features of psoriasis after injection of activated immunocytes [60]. IL-23-specific monoclonal antibodies prevented such lesions from developing, highlighting the pathogenic importance of Th17 cells [61].

Multiple T cell subsets, each producing a distinct range of cytokines, have been characterised that are relevant to the disease process, including CD4+ Th1, Th17 and Th22 that produce IFN $\gamma / \mathrm{TNF} \alpha$, IL-17/IL-22 and IL-22, respectively (Fig. 2) [62]. Naive CD4+ T cells differentiate into Th1 cells in the presence of IL-12 [63]; lineage specification of Th17 cells is regulated by IL-6, IL- $1 \beta$ and TGF- $\beta[64,65]$ and Th22 cells require TNF $\alpha$ and IL-6 [66, 67]. Subsequent exposure to IL-23 and IL-21 promotes the activation and proliferation of mature, inflammatory Th17 cells [65]. Since there are CD8+ T cells that produce the same cytokines as CD4+ Th17 cells, the term 'T17 cells' has been used to encompass all IL-17-producing cells, which also includes T cells expressing the non-variant $\gamma \delta$ T cell receptor $[68,69]$. Psoriatic skin lesions have greatly increased numbers of $\gamma \delta$ T cells compared with healthy controls, and an IL-17-producing $\gamma \delta$ T cell population has been identified in the dermis, which may be highly relevant in disease pathogenesis $[69,70]$.

\section{The role of cytokines in psoriasis}

\section{TNF $\alpha$}

$\mathrm{TNF} \alpha$ is produced by several different cells types in the context of cutaneous inflammation, including macrophages, keratinocytes, Th1 cells, T17 cells, Th22 cells and BDCA-1 - inflammatory DCs [71, 72]. Although parts of the literature are conflicting [73], there is evidence that circulating levels of $\mathrm{TNF} \alpha$ (in addition to IFN $\gamma$, IL-12) are elevated in psoriasis and correlate with disease severity [74, 75].

$\mathrm{TNF} \alpha$ regulates the ability of antigen presenting cells such as DCs to activate T cells [76]. It induces the expression of Creactive protein (part of the acute phase response), several cytokines such as IL-6 (which mediates T cell proliferation and keratinocyte hyperproliferation), and chemokines including CCL20 (recruits myeloid DCs and T17 cells) and IL-8 (for recruitment of neutrophils). Through the upregulation of intercellular adhesion molecule-I (ICAM-1), TNF $\alpha$ promotes the infiltration of inflammatory cells such as $\mathrm{T}$ cells and 


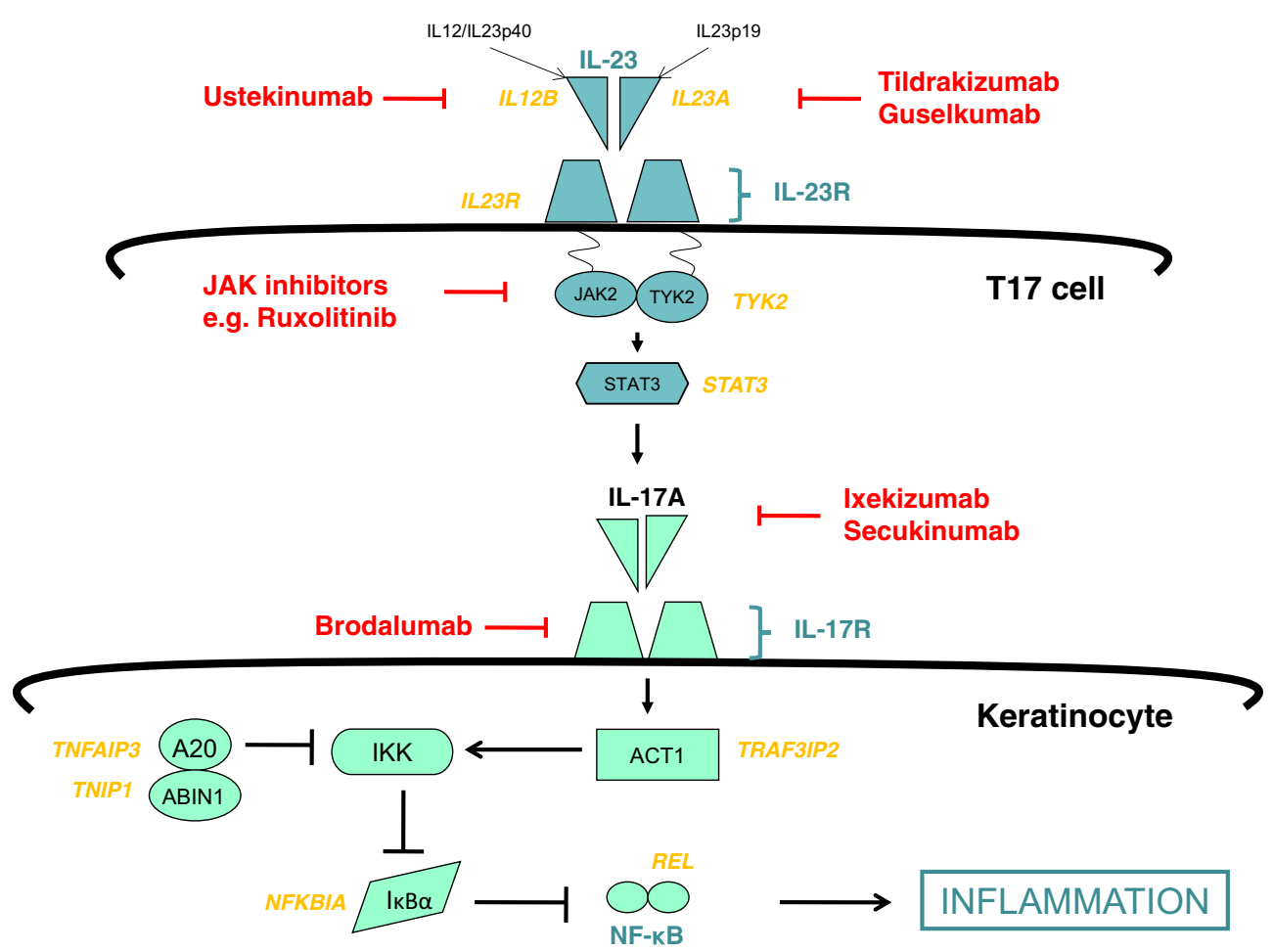

Fig. 3 The IL-23/T17 pathogenic axis is an important therapeutic target in psoriasis. IL-23 is a heterodimeric cytokine that is released by dendritic cells and binds to the IL-23 receptor (IL23R) on T17 cells. IL-23R is associated with Jak2 and Tyk2, which activate STAT3 molecules, resulting in the upregulation of IL-17A. Engagement of IL-17R on keratinocytes with IL-17A homodimers or IL-17A/IL-17F heterodimers induces the activation of NF- $\mathrm{KB}$ dimers, which translocate to the nucleus and drive the transcription of pro-inflammatory cytokines, chemokines and antimicrobial peptides. Numerous genes (yellow) encoding proteins involved in the IL-23/T17 pathway have been shown by genome-wide association studies to confer psoriasis susceptibility. Following activation

monocytes into the skin. It also facilitates IL-23 production by DCs and enhances the effects of other cytokines relevant to psoriasis pathogenesis such as IL-17. Therefore, TNF antagonists mediate part of their effect via suppression of the IL-23/ T17 axis [24].

$\mathrm{TNF} \alpha$ has a broad range of effects since TNF receptors (TNFR) are expressed on multiple cell types. There are two types of receptors, TNFR1 and TNFR2. Whereas TNFR2 is expressed predominantly on endothelial and haematopoietic cells, TNFR 1 is present on nearly all cell types [77]. Once activated by engagement with TNF $\alpha$, TNFR modulate multiple aspects of cell function such as proliferation, survival, activation, differentiation and apoptosis, by activating signalling cascades involving NF- $\mathrm{B}$, mitogen-activated protein kinase (MAPK) and c-Jun N-terminal kinase [78, 79]. Although $\mathrm{TNF} \alpha$ blockade is very effective therapeutically, which supports its role in disease pathogenesis, the diverse actions of the cytokine have resulted in numerous drug-associated side effects. Therefore, more targeted immunotherapies are now being investigated. of IL-17R, ACT1 (encoded by TRAF3IP2) interacts with TRAF proteins and the IKB kinase complex (IKK). IKK subsequently phosphorylates the inhibitory proteins $\mathrm{I} \kappa \mathrm{B}(\mathrm{I} \kappa \mathrm{B} \alpha$ is encoded by $N F K B I A)$, which normally form cytoplasmic complexes with NF-kB. Once phosphorylated, IkB is subject to ubiquitin-induced proteasomal degradation, resulting in the nuclear translocation of NF-kB. Further, the protein products of TNFAIP3 and TNIP1, A20 and ABIN1, respectively, physically interact to enable the ubiquitin-mediated destruction of NEMO (a regulatory protein that activates IKK). Several medications for psoriasis (red) target components of the IL-23/T17 immune axis

\section{IFN $\gamma$}

In addition to $\mathrm{TNF} \alpha$, Th1 cells are a key source of IFN $\gamma$, which is a type II IFN. It is also secreted by DCs and natural killer (NK) cells. Signal transducer and activator of transcription (STAT) 1 is activated downstream of IFN $\gamma$ and this regulates many genes that are found to be expressed in psoriatic skin lesions [80]. RNA microarrays have demonstrated that a large number of IFN $\gamma$-related genes are differentially regulated in psoriasis [81]. However, it was shown that antagonism of IFN $\gamma$ using a humanised monoclonal antibody does not significantly improve psoriasis [82]. Further, in a clinical trial of an IL-23-specific monoclonal antibody, there was no effect on IFNG expression in patients with psoriasis despite a complete clinical and histologic response, in contrast to the significant reduction in $I L 17$ messenger RNA levels observed [83]. This suggests that IFN $\gamma$ is not critical in sustaining chronic psoriasis lesions.

It is instead postulated that IFN $\gamma$ is more relevant in the early stages of disease, through the activation of antigen presenting cells [84]. It promotes the release of IL-1 and IL-23 
from DCs, which in turn drives T17 and Th22 cell differentiation and activation. IFN $\gamma$ also stimulates chemokines (e.g. CXCL10, CXCL11) and adhesion molecule release from keratinocytes, thus facilitating the recruitment of lymphocytes to inflammatory plaques. Although it is known to have an anti-proliferative effect on keratinocytes, this effect is abrogated in psoriatic lesions via the upregulation of suppressor of cytokine signalling (SOCS) 1 in response to high levels of IFN $\gamma[85]$.

\section{Type I IFN}

Type I IFNs comprise IFN $\alpha$ and IFN $\beta$, amongst others [86]. Several observations have indicated an important role for these cytokines in psoriasis development, particularly in the early stages. Treatment with type I IFN for conditions such as hepatitis and multiple sclerosis has been shown to exacerbate existing psoriasis vulgaris and induce new lesions [87, 88]. The type I IFN signalling pathway is activated in lesional keratinocytes and patients have abnormal serum levels of IFNs [89, 90]. In further support, an increase in IFN $\alpha$ level in xenograft mouse models precedes the development of psoriatic changes and anti-IFN $\alpha$ antibodies block classical psoriatic skin changes such as T cell infiltration into plaques [28].

As discussed above, plasmacytoid DCs, which infiltrate psoriatic skin lesions, are a major source of type I IFN [28] and this promotes myeloid DC phenotypic maturation and activation, thus facilitating T cell priming. Type I IFN signalling modulates the production of IFN $\gamma$ and IL-17 [91, 92] and has been implicated in the differentiation and activation of $\mathrm{T}$ cells, in particular Th1 and T17 cells [93]. Thus, it may drive downstream inflammatory circuits, leading to keratinocyte hyperproliferation. In addition to the indirect modulation of T cell responses via regulation of DCs, type I IFN may have direct pro-survival and pro-proliferative effects on T cells [94]. Finally, type I IFNs are rapidly induced in many different cell types in response to viral infections. Since genetic studies have indicated the importance of innate antiviral immune responses in psoriasis pathogenesis, this also underlines type I IFN as a critical disease cytokine. Specifically, several genes regulating type I IFN production (e.g. $D D X 58, I F I H 1$, RNF114) and signalling (e.g. TYK2) have been associated with disease susceptibility in GWAS.

\section{IL-23}

IL-23 is a heterodimer that is composed of an IL-23p19 subunit (encoded by IL23A) and IL-12/IL-23p40 (shared with IL12 and encoded by $I L 12 B$ ) (Fig. 3). It binds to IL-23R, which is associated with Jak2 and Tyk2. Engagement of the receptor triggers a signalling cascade that involves activation of STAT3. IL-23 is released by DCs and macrophages and mediates the terminal differentiation and activation of T17 cells (including induction of IL-17A and IFN $\gamma$ ), activation of keratinocytes and upregulation of TNF $\alpha$ expression in macrophages. Genetic studies that link single nucleotide polymorphisms in/near IL-23R, IL23A,IL12B, TYK2 and STAT3 with psoriasis susceptibility have highlighted IL-23 as a critical cytokine in disease pathogenesis [18-21]. In support, psoriasis lesions have elevated levels of IL-23 expression [95] and this is reversed after successful treatment with medications such as etanercept [96] and alefacept [97]. Further, anti-IL-12/IL-23 and anti-IL-23 agents are highly effective therapeutic agents [98]. Evidence from mouse models, in which psoriasiform histological changes arise from intradermal injection of IL23 or overexpression of IL-12/IL-23p40 in keratinocytes, also indicate the importance of this cytokine [99].

\section{IL-17A}

IL-17A belongs to the family of pro-inflammatory cytokines that comprises IL-17A-F [100]. It is overexpressed in psoriasis (both skin and blood [74, 101]) and its involvement in the immunopathogenesis of psoriasis has been increasingly recognised [102]. Given that IL-17 may promote the development of cardiovascular diseases [103], and the established link between psoriasis and such co-morbid conditions, targeting of IL-17 therapeutically may have benefits beyond the sole attenuation of skin inflammation. However, the biological effects of IL-17A in various tissues are complex. Indeed, it may also help to stabilise atherosclerotic plaques [104], which emphasises the need to enrol patients receiving IL-17 inhibitors in long-term safety registries.

Lesional psoriatic T cells produce large amounts of IL-17A when activated ex vivo; however, T cells from healthy skin do not produce IL-17A with the same stimuli [105]. Analysis of the psoriasis transcriptome also reveals enrichment for IL-17A genes [106]. More recently, IL-17A blocking agents have been shown to have rapid and high efficacy in clinical trials, as described later, further emphasising the pathogenic role of IL-17A signalling in psoriasis [107-109].

IL-17A is produced by T17 cells, neutrophils, mast cells and NK cells. Keratinocytes are the predominant cells that express IL-17 receptors (IL-17R; likely consisting of two IL17RA subunits complexed with one IL-17RC subunit) in psoriasis [110]. The active form of IL-17A consists of either IL17A homodimers or IL-17A-IL-17F heterodimers; the former having greater biological activity. Engagement of IL-17R induces the activation of NF- $\kappa \mathrm{B}$ signalling. GWAS have implicated several genes encoding components of the NF- $\mathrm{BB}$ pathway in psoriasis susceptibility including TNFAIP3, TNIP1, NFKBIA, REL and TRAP3IP2 (Fig. 3) [18-21]. For example, a loss of function coding variant in TRAP3IP2 is associated with psoriasis [20]. TRAP3IP2 encodes ACT1, which is involved in IL-17 signalling, and Act-1-deficient mice demonstrate upregulated T17 cell responses and spontaneous skin 
inflammation [111]. This underscores the immunological insights that can be gained from genetic data.

The downstream expression of a large number of genes in response to IL-17A has been shown in a three-dimensional human epidermis model (419 gene probes upregulated and 216 gene probes downregulated) [112]. Keratinocytes are stimulated by IL-17A to produce AMPs; pro-inflammatory cytokines such as IL-19 (driving epidermal hyperplasia), IL1, IL-6, and IL-23; and chemokines such as IL-8. In addition to promoting the mobilisation and activation of neutrophils, IL-8 is also a chemotaxin for T cells and NK cells. Although the role of regulatory $\mathrm{T}$ cells in the pathogenesis of psoriasis remains to be fully elucidated, IL-6 is thought to render effector $\mathrm{T}$ cells refractory to regulatory $\mathrm{T}$ cell-mediated suppression [113]. IL-17A also increases production of the chemokine CCL20 [114, 115] and ICAM-1, which facilitate cutaneous recruitment of DCs and T cells.

Taken together, IL-17A is crucial to establishing positive feedback loops such that epidermal hyperplasia and the cutaneous inflammatory response are sustained and amplified. For example, recruited DCs may secrete more IL-23, which promotes further T17 cell activation and hence release of IL-17A. This influences keratinocytes, leading to the recruitment of more DCs and T cells to the inflamed skin. IL-17 has recently been shown to act in synergy with $\mathrm{TNF} \alpha$ to induce proinflammatory cytokine production by keratinocytes [115]. Indeed, genes that are synergistically regulated by IL-17 and TNF $\alpha$ were more effectively blocked by anti-IL-17A than TNF antagonists [102], suggesting that IL-17A may have a dominant pathogenic effect.

\section{IL-22}

IL-22 is a member of the IL-10 family of cytokines and has been found to be upregulated in the skin and sera of patients with psoriasis $[116,117]$. Expression is also reduced following anti-psoriatic therapies [117]. The production of IL-22 by Th22 cells and Th17 cells is induced by IL-23 and it mediates multiple effects on keratinocytes, including hyperproliferation, differentiation, migration, and proinflammatory cytokine and AMP production [118, 119]. IL22 has been shown to act in synergy with IL-17A to induce AMP production by keratinocytes [120]. Blockade of IL-22 in vivo or genetic deletion caused reduced IL-23-induced epidermal hyperplasia [121], and IL-23-mediated epidermal hyperplasia in a murine model of psoriasiform skin inflammation was found to be dependent on IL-22 [121]. These data highlight potential crosstalk between the IL-23/T17 pathway and IL-22/Th22. However, in contrast to the IL-23/T17 pathway, there is a lack of genetic data in support of a role for IL-22 in disease pathogenesis. Further, trials of a human monoclonal antibody targeted against IL-22 (fezakinumab) were discontinued since preliminary analyses showed that the efficacy endpoints could not be achieved [122]. The negative findings from both genetics and clinical studies suggest that IL-22 may not be as critical to the disease process as had initially been anticipated from earlier immunological studies.

\section{Pustular psoriasis}

Pustular psoriasis is a rare, severe subtype of psoriasis that has been shown by genetic studies to have a distinct aetiology from psoriasis vulgaris. In particular, a lack of association of pustular psoriasis with the PSORS1 locus has been demonstrated, in striking contrast to psoriasis vulgaris [123]. It is characterised clinically by the presence of sterile pustules on variably erythematous skin and histologically by diffuse dermal neutrophilic infiltration and micropustules in the epidermis [124, 125]. It encompasses generalised pustular psoriasis, in which patients experience acute flares of widespread cutaneous pustulation associated with systemic upset, and chronic, localised forms such as palmoplantar psoriasis and acrodermatitis continua of Hallopeau.

Recently, IL-1 family cytokines have been shown to have a potential pathogenic role in pustular psoriasis since loss of function, autosomal recessive mutations in $I L 36 R N$ were described in association with this disease subtype [126-128]. Targeted sequencing studies further revealed that mutations in IL36RN are not associated with psoriasis vulgaris, emphasising distinct pathogenic mechanisms for pustular and plaque forms of psoriasis and the potential for stratification of psoriasis subtypes using genetic biomarkers [129]. IL36RN encodes an antagonist (IL-36Ra) that blocks innate immune IL-1 family cytokines (IL-36 $\alpha$, IL-36 $\beta$ and IL$36 \gamma$ ) from binding to their receptor (IL-1RL2) [130]. This prevents subsequent activation of the NF- $\mathrm{KB}$ pathway. Therefore, IL-36Ra deficiency leads to unopposed IL-1 activity that may result in the significant cutaneous neutrophil recruitment that is observed in pustular psoriasis. IL-36 cytokines also cause upregulation of IL-23 by DCs and keratinocytes [131], IL-6 and IL-8, which helps to sustain cutaneous inflammation.

In further support of a role for aberrant IL-1 signalling in pustular psoriasis, the disease is associated with pathogenic mutations in $A P 1 S 3$, silencing of which has been shown to disrupt the endosomal translocation of Toll-like receptor 3 (TLR3), leading to impaired IFN $\beta$ induction [132]. Given that IFN $\beta$ downregulates the production of IL-1 [133], it is possible that mutations in $A P 1 S 3$, which encodes a subunit of adaptor protein complex 1 and is involved in clathrin-mediated vesicular transport of proteins between the trans-Golgi network and endosomes, result in IL-1 over-production. By virtue of the aforementioned pathogenic insights delivered by 
genetic studies, IL-1 blockade is now emerging as a promising therapeutic strategy for this clinical variant.

Pustular psoriasis is also associated with missense mutations in CARD14 [134-136]. CARD14 is highly expressed in the skin and encodes a protein involved in TRAF2-dependent NF-KB activation [137]. It has been previously implicated in psoriasis vulgaris [138], which suggests some potential shared disease pathways in distinct subtypes of psoriasis.

\section{Update on therapeutics}

As the pathogenic mechanisms have become better defined, there has been a shift towards the design of more targeted treatments in psoriasis (Table 1). Specific cytokines pertinent to the development of disease have been selected as drug targets in the hope of effective suppression of pathogenic immune responses whilst reducing the risk of global suppression of protective immunity, thus potentially improving the safety profiles of the medications.

\section{TNF antagonists}

TNF antagonists have proven to be highly effective for the treatment of psoriasis. The three agents currently approved for use in moderate/severe psoriasis are infliximab, a chimeric neutralising monoclonal antibody, adalimumab, a fully humanised IgG1 monoclonal antibody, and etanercept, a recombinant fusion protein comprising an Fc domain of human IgG1 monoclonal antibody and the ligand binding domain of the TNF $\alpha$ receptor. Effective treatment causes decreased numbers of T cells and DCs and reduced levels of their secreted cytokines [24, 139]. In particular, successful therapy was found to be associated with downregulation of genes involved in the differentiation and function of Th17 cells, suggesting that TNF antagonists exert their effect via the modulation of the IL-23/T17 axis. This may be attributable to TNF $\alpha$ promoting IL-23 synthesis in DCs. Etanercept treatment was also shown to reduce lesional DC expression of co-stimulatory molecules in vitro, thus impairing DC-T cell interactions and the activation of allogeneic T cells [24].

However, blockade of TNF $\alpha$ may lead to serious adverse events, including reactivation of latent tuberculosis, and this has prompted more rigorous screening investigations prior to commencing all biologic agents [140]. Some studies have also described an association between treatment and an increased incidence of malignancy such as lymphoma [141, 142]. There are reports of TNF antagonists rarely promoting the development of demyelinating disease, and a potential underlying mechanism has been unravelled through the discovery of a multiple sclerosisassociated genetic variant that translates into the production of an endogenous TNF antagonist called $\triangle 6$-TNFR1 $[143,144]$. This soluble protein comprises the extracellular domain of TNFR1, but lacks the transmembrane or cytoplasmic domains. It can bind and neutralise TNF with high affinity, thus preventing potentially neuroprotective cellular signalling through membrane-bound TNFR1. Finally, TNF antagonists have been associated with a de novo, paradoxical onset of pustular psoriasis mostly located on the palms and/or soles, for which a mechanism is currently unknown [145].

Table 1 Targeted therapies for psoriasis

\begin{tabular}{llll}
\hline Therapeutic agent & Target & Agent type & Stage of development \\
\hline Infliximab & TNF $\alpha$ & Chimeric monoclonal antibody & Approved \\
Adalimumab & TNF $\alpha$ & Human monoclonal antibody & Approved \\
Etanercept & TNF $\alpha$ & Soluble TNF $\alpha$ receptor-IgG fusion protein & Approved \\
Ustekinumab & IL-12/IL-23p40 & Human monoclonal antibody & Approved \\
Tildrakizumab, guselkumab & IL-23p19 & Human monoclonal antibody & Phase III studies ongoing \\
Ixekizumab & IL-17A & Humanised monoclonal antibody phase III & Studies ongoing \\
Secukinumab & IL-17A & Human monoclonal antibody & Approved \\
Brodalumab & IL-17RA & Human monoclonal antibody & Development halted \\
Apremilast & PDE-4 & Small molecule inhibitor & Approved \\
Tofacitinib & JAK1/JAK3 & Small molecule inhibitor & Phase III studies completed; under FDA review \\
Ruxolitinib & JAK1/JAK2 & Small molecule inhibitor & Phase II studies completed \\
CF101 & A 3 adenosine receptor & Small molecule agonist & Phase II/III studies completed \\
Anakinra & IL-1R & Soluble recombinant IL-1Ra & Phase II study ongoing \\
MABp1 & IL-1 $\alpha$ & Humanised monoclonal antibody & Phase II study completed \\
Canakinumab & IL-1 $\beta$ & Human monoclonal antibody & Not currently in trial \\
Gevokizumab & IL-1 $\beta$ & Humanised monoclonal antibody & Not currently in trial \\
\hline
\end{tabular}




\section{IL-12/IL-23 inhibitors}

Since the characterisation of a dominant pathogenic role for the IL-23/T17 axis in psoriasis by GWAS, several drugs targeted against components of this pathway have been studied with reported successful outcomes (Fig. 3). Ustekinumab is a Food and Drug Administration (FDA)-approved humanised monoclonal antibody that neutralises the p40 subunit common to IL-23 and IL-12. The antibody prevents the binding of IL-23 and IL-12 to their receptors, thus inhibiting T17 and Th1 signalling pathways. It has been shown to be a highly efficacious treatment, with greater than $60 \%$ of treated patients achieving at least $75 \%$ reduction in their baseline Psoriasis and Severity Index (PASI-75) at 12 weeks compared with $3 \%$ of the control group [146, 147]. There is also a reported superior clinical effect compared with etanercept [148], suggesting that IL-23 may have a more prominent role than TNF $\alpha$ in psoriasis pathogenesis. Indeed, IL-23 levels remain high in patients who fail TNF antagonists, which enable ongoing T17 activation [139]. Although limited followup data is available, the safety profile of ustekinumab to date appears to be more favourable than TNF antagonists, which may be due to the intact $\mathrm{TNF} \alpha$-mediated innate immune responses that result from IL-23 antagonism.

There are emerging reports of successful treatment of different subtypes of pustular psoriasis with ustekinumab [149-152]. However, the case reported of successful treatment of acrodermatitis of Hallopeau, a severe and often refractory form of pustular psoriasis affecting distal fingers and toes, required co-therapy with acitretin and higher than standard doses of ustekinumab in order to achieve complete clinical resolution [151]. Further assessment of this medication within adequately powered clinical trials is thus warranted; however, this is challenging given the lower prevalence of this form of psoriasis.

There are encouraging results from clinical studies of monoclonal antibodies that target the unique $\mathrm{p} 19$ subunit of IL-23 in psoriasis vulgaris [153]. Seventy-four percent of patients treated with tildrakizumab, a monoclonal anti-p19 IgG1, achieved PASI-75 after 16 weeks compared with $4.4 \%$ of individuals in the placebo group in a phase II trial. In a study of guselkumab (anti-p19), $81 \%$ of patients achieved PASI-75 after 16 weeks in the treatment group, compared with $71 \%$ of those receiving adalimumab and $4.8 \%$ of those receiving placebo.

\section{IL-17 inhibitors}

IL-17A is a central driver in disease pathogenesis; hence, IL17 inhibitors have been extensively researched for the treatment of psoriasis. Secukinumab and ixekizumab are neutralising humanised monoclonal antibodies (IgG4 and
IgG1, respectively) that bind to IL-17A and brodalumab binds to the IL-17 receptor A subunit.

Secukinumab received FDA approval for the treatment of moderate/severe psoriasis in January 2015. It demonstrated clinical efficacy in phase II trials, with $82 \%$ of treated patients achieving PASI- 75 compared with $9 \%$ of those receiving placebo [154]. This agent was shown to be more effective than etanercept in the 52-week randomised, double-blind, placebocontrolled, parallel-group, phase III FIXTURE study, with similar incidences of adverse events [155]. The trial also showed more rapid effects with secukinumab as clinical response (defined as a $50 \%$ reduction in mean PASI) was achieved sooner with secukinumab (median 3 weeks with $300 \mathrm{mg}$ and 3.9 weeks with $150 \mathrm{mg}$ ) than etanercept (median 7 weeks). Candidal infections were more common in those treated with secukinumab than etanercept, which is likely attributable to the important role for IL-17A in mucocutaneous immunity against fungi. All candidal infections were, however, either self-limited or resolved with standard treatments and none required cessation of secukinumab. A second randomised phase III trial (ERASURE), comparing secukinumab with placebo, demonstrated superior responses in the treatment group at 12 weeks [155].

Phase II trial data of ixekizumab showed that $82 \%$ of treated patients achieved PASI-75 at 12 weeks with no associated serious adverse events [109]. A rapid clinical response was observed, with many achieving near maximal improvement within the first 6 weeks of treatment, which is faster than that observed with other available therapies, including TNF antagonists. Phase III studies of ixekizumab are ongoing (https://clinicaltrials.gov).

Mechanistic studies have demonstrated decreased expression of a broad range of immune-related genes in response to secukinumab treatment, including T17-related transcripts (IL22, IL17F and IL8), Th1-related genes (IFNG and IL12B) and other innate immune inflammatory genes $(T N F, I L 6$ and $I L 1 B$ ), which may account for the potency of the medication [156]. There also was evidence of decreased epidermal hyperplasia, indicating keratinocyte modulation, and reduced infiltration of $\mathrm{CD} 3+$ and IL-17+ cells in lesions. A later study showed a reduction in the inflammatory cell infiltrate $(\mathrm{CD} 3+, \mathrm{CD} 11 \mathrm{c}+$ and CD-LAMP+ cells) in response to ixekizumab, indicating effects on both $\mathrm{T}$ cells and DCs [102]. The medication modulated gene expression rapidly, with normalisation (i.e. reduction by at least $75 \%$ ) of $60 \%$ of transcriptome genes relevant to psoriasis after only 2 weeks, compared with $10 \%$ of disease-related genes normalised by etanercept. This study also highlighted the wide-ranging effects of IL-17, since hundreds of psoriasis-associated genes were normalised by ixekizumab.

Brodalumab has a potentially wider range of action as it antagonises the receptor that binds IL-17A, IL-17F and IL$17 \mathrm{~A} / \mathrm{F}$ heterodimers. A phase II clinical trial showed that $82 \%$ 
of treated patients reached PASI-75 at week 12 [107], and phase III studies demonstrated superior efficacy of brodalumab compared with both placebo and ustekinumab for all primary endpoints [157]. Despite these promising reports, there has been recent concern over potential links between brodalumab and suicidal ideation since two patients enrolled in the published clinical studies committed suicide. Although no causality has been established between these events and brodalumab, it underlines our current relatively limited understanding of the safety profiles of these medications.

\section{Phosphodiesterase inhibitors}

The oral phosphodiesterase-4 (PDE-4) inhibitor apremilast prevents the conversion of 3 '-5'-cyclic adenosine monophosphate (cAMP) to AMP. Its beneficial effect is thus attributable to increased levels of cAMP, which reduces inflammation by downregulating cytokines such as TNF $\alpha$ and IL-23. It also upregulates the production of anti-inflammatory molecules such as IL-10 [158]. Phase II and III study data demonstrated superior benefit in the treatment groups compared to placebo, with a favourable safety profile reported, and it was approved by the FDA and European Medicines Agency (EMA) for the treatment of moderate/severe psoriasis in 2014 [159].

\section{Janus kinase inhibitors}

Janus kinases (JAK) are cytoplasmic protein tyrosine kinases that mediate the activation of STAT proteins. JAK/STAT intracellular signalling regulates the expression of proinflammatory genes. Numerous cytokines that are upregulated in psoriatic skin lesions and involved in $\mathrm{T}$ cell proliferation, activation and survival, such as type I and III IFNs and IL-23, use the JAK/STAT pathway; however, there some exceptions, including TNF $\alpha$ and IL-17. There are four members of the JAK family, JAK1, JAK2, JAK3 and TYK2. JAKs act in pairs and the novel inhibitors that are currently being evaluated in clinical trials have varying efficacy for each of the JAKs. TYK2 is involved in modulation of T17 cell responses, and although there are no selective TYK2 inhibitors currently in clinical trials, the pathogenic missense mutations in TYK2 discovered by GWAS emphasise its role in disease pathogenesis and the utility of pursuing it as a novel drug target [19].

Tofacitinib is a small molecule that preferentially inhibits JAK1 and JAK3. Phase II study data demonstrated a PASI-75 response in $67 \%$ of patients with moderate/severe plaque psoriasis receiving $15 \mathrm{mg}$ daily [160]. In this study, the side effects included dose-dependent increases in lipids (which returned to baseline after cessation of treatment) and mild decreases in haemoglobin and neutrophil counts. Although small molecules generally have less efficacy when compared with biologic agents, their associated advantages include oral administration (or topical, as below) and reduced cost.

Small molecules less than $500 \mathrm{Da}$ in molecular weight are able to cross the stratum corneum, so may be used as topical treatments [161]. Topical $2 \%$ tofacitinib formulations were well tolerated and showed promising efficacy in a recent vehicle-controlled trial [162]. Ruxolitinib predominantly inhibits JAK1 and JAK2 and topical formulations have previously been tested [163]. This demonstrated a $53 \%$ and $54 \%$ decrease in mean 'total lesion score' (assessing scaling, redness and thickness) after treatment with $1 \%$ and $1.5 \%$ ruxolitinib ointments, respectively, compared with $32 \%$ for vehicle. No significant adverse effects were reported.

\section{$A_{3}$ adenosine receptor agonists}

$A_{3}$ adenosine receptors $\left(A_{3} A R\right)$ are $G$ protein coupled receptors that bind to adenosine. They were found to be highly expressed in peripheral blood mononuclear cells from psoriasis patients [164]. Activation of $\mathrm{A}_{3} \mathrm{AR}$ by the agonist CF101 has been shown to reduce NF- $\mathrm{kB}$ signalling and promote apoptosis of inflammatory cells. Pro-inflammatory cytokines such as TNF $\alpha$, IL-6 and IL-12 are also downregulated. CF101 has subsequently been tested in a phase II clinical trial [165]. Orally administered CF101 (2 mg twice daily) resulted in a PASI-50 response in $35.3 \%$ of patients, with only mild side effects reported.

\section{IL-1 antagonists}

Given the potential importance of dysregulated IL-1 signalling in the pathogenesis of pustular psoriasis, IL-1 blockers have been investigated for use in the treatment of this clinical phenotype, with successful cases described [166-168]. The agent anakinra has been used, which is a recombinant form of the IL-1 receptor antagonist (IL-1Ra) that prevents both IL$1 \alpha$ and IL- $1 \beta$ signalling. However, randomised control trial data is lacking and the reported cases of incomplete clinical response suggest that IL-1 signalling may not play a dominant pathogenic role in all patients with pustular psoriasis [151, 169-171].

\section{Conclusion}

A limitation of the current clinical studies is the lack of longterm data, which is particularly relevant when considering the safety profile of the medications. For example, efalizumab was first approved in 2003 for the treatment of moderate/ severe psoriasis but later withdrawn from the market in 2009 due to safety concerns. It is a humanised, monoclonal antibody that blocks the interaction between CD11a/LFA-1 on T cells and ICAM-1 on antigen presenting cells. Efalizumab was 
withdrawn after progressive multifocal leukoencephalopathy, a potentially fatal central nervous system infection associated with immunosuppression, was reported in four patients receiving treatment [172]. Further, although biosimilar alternatives to biological agents that have lost their patent protection are of considerable financial interest, the importance of critical assessments of their safety, quality and efficacy relative to the biological reference product prior to use in patients must be emphasised [173].

Careful monitoring of all new and existing therapies and recording of data in multi-centre, large-scale registries are vital to ensuring adverse events are promptly recognised. It will also be important for clinical studies to stratify patients according to detailed phenotype and genotype information. This will help to identify biomarkers of drug response and represent a shift towards the practice of personalised medicine, in which an individual is prescribed a specific treatment that is predicted to have therapeutic success and a favourable safety profile, on the basis of their genetic profile.

Although further research is warranted, current clinical trial data on new treatments are helping to improve our understanding of the immunopathogenesis of psoriasis. Indeed, psoriasis research is a leading example of the translational potential of data from basic science studies such as GWAS, which have delivered mechanistic insights into disease pathways. These have subsequently informed the design of powerful new treatments that are able to act faster, more effectively and in a more targeted manner. Improved specificity of drug targets reduces the chance of ameliorating the body's protective immunity against microbes, which is currently a limitation of agents such as TNF antagonists. Although late-stage clinical trials for several medications are still underway, there appears to be increasing hope for the millions of individuals worldwide suffering from this debilitating and disfiguring disease.

Open Access This article is distributed under the terms of the Creative Commons Attribution 4.0 International License (http:// creativecommons.org/licenses/by/4.0/), which permits unrestricted use, distribution, and reproduction in any medium, provided you give appropriate credit to the original author(s) and the source, provide a link to the Creative Commons license, and indicate if changes were made.

\section{References}

1. Gelfand JM, Feldman SR, Stern RS, Thomas J, Rolstad T, Margolis DJ (2004) Determinants of quality of life in patients with psoriasis: a study from the US population. J Am Acad Dermatol 51(5):704-708

2. Gelfand JM, Neimann AL, Shin DB, Wang X, Margolis DJ, Troxel AB (2006) Risk of myocardial infarction in patients with psoriasis. JAMA 296(14):1735-1741

3. Nestle FO, Kaplan DH, Barker J (2009) Psoriasis. N Engl J Med 361(5):496-509
4. Boehncke W-H, Schön MP (2015) Psoriasis. Lancet Lond Engl 386(9997):983-994

5. Mahil SK, Capon F, Barker JN (2015) Genetics of psoriasis. Dermatol Clin 33(1):1-11

6. Capon F, Burden AD, Trembath RC, Barker JN (2012) Psoriasis and other complex trait dermatoses: from Loci to functional pathways. J Invest Dermatol 132(3 Pt 2):915-922

7. Murphy M, Kerr P, Grant-Kels JM (2007) The histopathologic spectrum of psoriasis. Clin Dermatol 25(6):524-528

8. Lande R, Gregorio J, Facchinetti V, Chatterjee B, Wang Y-H, Homey B et al (2007) Plasmacytoid dendritic cells sense selfDNA coupled with antimicrobial peptide. Nature 449(7162): 564-569

9. Gilliet M, Lande R (2008) Antimicrobial peptides and self-DNA in autoimmune skin inflammation. Curr Opin Immunol 20(4): $401-407$

10. Lande R, Botti E, Jandus C, Dojcinovic D, Fanelli G, Conrad C et al (2014) The antimicrobial peptide LL37 is a T-cell autoantigen in psoriasis. Nat Commun 5:5621

11. Ganguly D, Chamilos G, Lande R, Gregorio J, Meller S, Facchinetti V et al (2009) Self-RNA-antimicrobial peptide complexes activate human dendritic cells through TLR7 and TLR8. J Exp Med 206(9):1983-1994

12. Van der Fits L, Mourits S, Voerman JSA, Kant M, Boon L, Laman $\mathrm{JD}$, et al. Imiquimod-induced psoriasis-like skin inflammation in mice is mediated via the IL-23/IL-17 axis. J Immunol Baltim Md 1950. 2009 May 1;182(9):5836-45.

13. Trembath RC, Clough RL, Rosbotham JL, Jones AB, Camp RD, Frodsham A et al (1997) Identification of a major susceptibility locus on chromosome $6 \mathrm{p}$ and evidence for further disease loci revealed by a two stage genome-wide search in psoriasis. Hum Mol Genet 6(5):813-820

14. Nair RP, Henseler T, Jenisch S, Stuart P, Bichakjian CK, Lenk W et al (1997) Evidence for two psoriasis susceptibility loci (HLA and $17 q)$ and two novel candidate regions (16q and $20 p)$ by genome-wide scan. Hum Mol Genet 6(8):1349-1356

15. Veal CD, Capon F, Allen MH, Heath EK, Evans JC, Jones A et al (2002) Family-based analysis using a dense single-nucleotide polymorphism-based map defines genetic variation at PSORS1, the major psoriasis-susceptibility locus. Am J Hum Genet 71(3): 554-564

16. Capon F, Munro M, Barker J, Trembath R (2002) Searching for the major histocompatibility complex psoriasis susceptibility gene. J Invest Dermatol 118(5):745-751

17. Nair RP, Stuart PE, Nistor I, Hiremagalore R, Chia NVC, Jenisch $\mathrm{S}$ et al (2006) Sequence and haplotype analysis supports HLA-C as the psoriasis susceptibility 1 gene. Am J Hum Genet 78(5):827851

18. Nair RP, Duffin KC, Helms C, Ding J, Stuart PE, Goldgar D et al (2009) Genome-wide scan reveals association of psoriasis with IL-23 and NF-kappaB pathways. Nat Genet 41(2):199-204

19. Genetic Analysis of Psoriasis Consortium \& the Wellcome Trust Case Control Consortium 2, Strange A, Capon F, Spencer CCA, Knight J, Weale ME, Strange A, Capon F, Spencer CCA, Knight J, Weale ME et al (2010) A genome-wide association study identifies new psoriasis susceptibility loci and an interaction between HLA-C and ERAP1. Nat Genet 42(11):985-990

20. Ellinghaus E, Ellinghaus D, Stuart PE, Nair RP, Debrus S, Raelson JV et al (2010) Genome-wide association study identifies a psoriasis susceptibility locus at TRAF3IP2. Nat Genet 42(11):991-995

21. Tsoi LC, Spain SL, Knight J, Ellinghaus E, Stuart PE, Capon F et al (2012) Identification of 15 new psoriasis susceptibility loci highlights the role of innate immunity. Nat Genet 44(12):13411348

22. Nestle FO, Turka LA, Nickoloff BJ (1994) Characterization of dermal dendritic cells in psoriasis. Autostimulation of $\mathrm{T}$ 
lymphocytes and induction of Th1 type cytokines. J Clin Invest 94(1):202-209

23. Johnson-Huang LM, McNutt NS, Krueger JG, Lowes MA (2009) Cytokine-producing dendritic cells in the pathogenesis of inflammatory skin diseases. J Clin Immunol 29(3):247-256

24. Zaba LC, Cardinale I, Gilleaudeau P, Sullivan-Whalen M, SuárezFariñas M, Suárez Fariñas M et al (2007) Amelioration of epidermal hyperplasia by TNF inhibition is associated with reduced Th17 responses. J Exp Med 204(13):3183-3194

25. Johnson-Huang LM, Suárez-Fariñas M, Sullivan-Whalen M, Gilleaudeau P, Krueger JG, Lowes MA (2010) Effective narrowband UVB radiation therapy suppresses the IL-23/IL-17 axis in normalized psoriasis plaques. J Invest Dermatol 130(11):26542663

26. Schmid P, Itin P, Cox D, McMaster GK, Horisberger MA (1994) The type I interferon system is locally activated in psoriatic lesions. J Interferon Res 14(5):229-234

27. Wollenberg A, Wagner M, Günther S, Towarowski A, Tuma E, Moderer M et al (2002) Plasmacytoid dendritic cells: a new cutaneous dendritic cell subset with distinct role in inflammatory skin diseases. J Invest Dermatol 119(5):1096-1102

28. Nestle FO, Conrad C, Tun-Kyi A, Homey B, Gombert M, Boyman $\mathrm{O}$ et al (2005) Plasmacytoid predendritic cells initiate psoriasis through interferon-alpha production. J Exp Med 202(1):135-143

29. Boehncke W-H, Schön MP (2007) Animal models of psoriasis. Clin Dermatol 25(6):596-605

30. Cumberbatch M, Singh M, Dearman RJ, Young HS, Kimber I, Griffiths CEM (2006) Impaired Langerhans cell migration in psoriasis. J Exp Med 203(4):953-960

31. Shaw FL, Cumberbatch M, Kleyn CE, Begum R, Dearman RJ, Kimber I et al (2010) Langerhans cell mobilization distinguishes between early-onset and late-onset psoriasis. J Invest Dermatol 130(7):1940-1942

32. Shaw FL, Mellody KT, Ogden S, Dearman RJ, Kimber I, Griffiths CEM (2014) Treatment-related restoration of Langerhans cell migration in psoriasis. J Invest Dermatol 134(1):268-271

33. De Cid R, Riveira-Munoz E, Zeeuwen PLJM, Robarge J, Liao W, Dannhauser EN et al (2009) Deletion of the late cornified envelope LCE3B and LCE3C genes as a susceptibility factor for psoriasis. Nat Genet 41(2):211-215

34. Bergboer JGM, Zeeuwen PLJM, Schalkwijk J (2012) Genetics of psoriasis: evidence for epistatic interaction between skin barrier abnormalities and immune deviation. J Invest Dermatol 132(10): 2320-2331

35. Hollox EJ, Huffmeier U, Zeeuwen PLJM, Palla R, Lascorz J, Rodijk-Olthuis D et al (2008) Psoriasis is associated with increased beta-defensin genomic copy number. Nat Genet 40(1): 23-25

36. Jansen PAM, Rodijk-Olthuis D, Hollox EJ, Kamsteeg M, Tjabringa GS, de Jongh GJ et al (2009) Beta-defensin-2 protein is a serum biomarker for disease activity in psoriasis and reaches biologically relevant concentrations in lesional skin. PLoS One 4(3): 4725

37. Gambichler T, Kobus S, Kobus A, Tigges C, Scola N, Altmeyer P et al (2011) Expression of antimicrobial peptides and proteins in etanercept-treated psoriasis patients. Regul Pept 167(2-3):163166

38. Lamkanfi M, Dixit VM (2014) Mechanisms and functions of inflammasomes. Cell 157(5):1013-1022

39. Dinarello CA (1999) IL-18: A TH1-inducing, proinflammatory cytokine and new member of the IL-1 family. J Allergy Clin Immunol 103(1 Pt 1):11-24

40. Chung Y, Chang SH, Martinez GJ, Yang XO, Nurieva R, Kang HS et al (2009) Critical regulation of early Th17 cell differentiation by interleukin-1 signaling. Immunity 30(4): 576-587

41. Prens EP, Kant M, van Dijk G, van der Wel LI, Mourits S, van der Fits L (2008) IFN-alpha enhances poly-IC responses in human keratinocytes by inducing expression of cytosolic innate RNA receptors: relevance for psoriasis. J Invest Dermatol 128(4):932938

42. Capon F, Bijlmakers M-J, Wolf N, Quaranta M, Huffmeier U, Allen M et al (2008) Identification of ZNF313/RNF114 as a novel psoriasis susceptibility gene. Hum Mol Genet 17(13):1938-1945

43. Bijlmakers M-J, Kanneganti SK, Barker JN, Trembath RC, Capon F (2011) Functional analysis of the RNF114 psoriasis susceptibility gene implicates innate immune responses to double-stranded RNA in disease pathogenesis. Hum Mol Genet 20(16):3129-3137

44. Xia Y-P, Li B, Hylton D, Detmar M, Yancopoulos GD, Rudge JS (2003) Transgenic delivery of VEGF to mouse skin leads to an inflammatory condition resembling human psoriasis. Blood 102(1):161-168

45. Terui T, Ozawa M, Tagami H (2000) Role of neutrophils in induction of acute inflammation in T-cell-mediated immune dermatosis, psoriasis: a neutrophil-associated inflammation-boosting loop. Exp Dermatol 9(1):1-10

46. Knight JS, Carmona-Rivera C, Kaplan MJ (2012) Proteins derived from neutrophil extracellular traps may serve as self-antigens and mediate organ damage in autoimmune diseases. Front Immunol 3: 380

47. Lin AM, Rubin CJ, Khandpur R, Wang JY, Riblett M, Yalavarthi S, et al. Mast cells and neutrophils release IL-17 through extracellular trap formation in psoriasis. J Immunol Baltim Md 1950. 2011 Jul 1;187(1):490-500.

48. Meyer-Hoffert U, Wingertszahn J, Wiedow O (2004) Human leukocyte elastase induces keratinocyte proliferation by epidermal growth factor receptor activation. J Invest Dermatol 123(2):338 345

49. Reich K, Papp KA, Matheson RT, Tu JH, Bissonnette R, Bourcier $\mathrm{M}$ et al (2015) Evidence that a neutrophil-keratinocyte crosstalk is an early target of IL-17A inhibition in psoriasis. Exp Dermatol 24(7):529-535

50. Stratis A, Pasparakis M, Rupec RA, Markur D, Hartmann K, Scharffetter-Kochanek K et al (2006) Pathogenic role for skin macrophages in a mouse model of keratinocyte-induced psoriasis-like skin inflammation. J Clin Invest 116(8):2094-2104

51. Wang H, Peters T, Kess D, Sindrilaru A, Oreshkova T, Van Rooijen N et al (2006) Activated macrophages are essential in a murine model for $\mathrm{T}$ cell-mediated chronic psoriasiform skin inflammation. J Clin Invest 116(8):2105-2114

52. Fuentes-Duculan J, Suárez-Fariñas M, Zaba LC, Nograles KE, Pierson KC, Mitsui $\mathrm{H}$ et al (2010) A subpopulation of CD163positive macrophages is classically activated in psoriasis. J Invest Dermatol 130(10):2412-2422

53. Capon F, Di Meglio P, Szaub J, Prescott NJ, Dunster C, Baumber $L$ et al (2007) Sequence variants in the genes for the interleukin-23 receptor (IL23R) and its ligand (IL12B) confer protection against psoriasis. Hum Genet 122(2):201-206

54. Di Meglio P, Di Cesare A, Laggner U, Chu C-C, Napolitano L, Villanova $F$ et al (2011) The IL23R R381Q gene variant protects against immune-mediated diseases by impairing IL-23-induced Th17 effector response in humans. PLoS One 6(2), e17160

55. Bos JD, Hulsebosch HJ, Krieg SR, Bakker PM, Cormane RH (1983) Immunocompetent cells in psoriasis. In situ immunophenotyping by monoclonal antibodies. Arch Dermatol Res 275(3):181-189

56. Gottlieb SL, Gilleaudeau P, Johnson R, Estes L, Woodworth TG, Gottlieb AB et al (1995) Response of psoriasis to a lymphocyteselective toxin (DAB389IL-2) suggests a primary immune, but not keratinocyte, pathogenic basis. Nat Med 1(5):442-447 
57. Abrams JR, Lebwohl MG, Guzzo CA, Jegasothy BV, Goldfarb MT, Goffe BS et al (1999) CTLA4Ig-mediated blockade of T-cell costimulation in patients with psoriasis vulgaris. J Clin Invest 103(9):1243-1252

58. Chamian F, Lin S-L, Lee E, Kikuchi T, Gilleaudeau P, SullivanWhalen $M$ et al (2007) Alefacept (anti-CD2) causes a selective reduction in circulating effector memory $\mathrm{T}$ cells $(\mathrm{Tem})$ and relative preservation of central memory T cells (Tcm) in psoriasis. J Transl Med 5:27

59. Boehncke WH, Dressel D, Zollner TM, Kaufmann R (1996) Pulling the trigger on psoriasis. Nature 379(6568):777

60. Wrone-Smith T, Nickoloff BJ (1996) Dermal injection of immunocytes induces psoriasis. J Clin Invest 98(8):1878-1887

61. Tonel G, Conrad C, Laggner U, Di Meglio P, Grys K, McClanahan TK et al (2010) Cutting edge: a critical functional role for IL-23 in psoriasis. J Immunol Baltim Md 185(10):56885691

62. Kagami S, Rizzo HL, Lee JJ, Koguchi Y, Blauvelt A (2010) Circulating Th17, Th22, and Th1 cells are increased in psoriasis. J Invest Dermatol 130(5):1373-1383

63. Manetti R, Parronchi P, Giudizi MG, Piccinni MP, Maggi E, Trinchieri G et al (1993) Natural killer cell stimulatory factor (interleukin 12 [IL-12]) induces T helper type 1 (Th1)-specific immune responses and inhibits the development of IL-4producing Th cells. J Exp Med 177(4):1199-1204

64. Bettelli E, Korn T, Oukka M, Kuchroo VK (2008) Induction and effector functions of T(H)17 cells. Nature 453(7198):1051-1057

65. Gaffen SL, Jain R, Garg AV, Cua DJ (2014) The IL-23-IL-17 immune axis: from mechanisms to therapeutic testing. Nat Rev Immunol 14(9):585-600

66. Duhen T, Geiger R, Jarrossay D, Lanzavecchia A, Sallusto F (2009) Production of interleukin 22 but not interleukin 17 by a subset of human skin-homing memory T cells. Nat Immunol 10(8):857-863

67. Trifari S, Kaplan CD, Tran EH, Crellin NK, Spits H (2009) Identification of a human helper $\mathrm{T}$ cell population that has abundant production of interleukin 22 and is distinct from $\mathrm{T}(\mathrm{H})-17$, $\mathrm{T}(\mathrm{H}) 1$ and $\mathrm{T}(\mathrm{H}) 2$ cells. Nat Immunol 10(8):864-871

68. Lowes MA, Suárez-Fariñas M, Krueger JG (2014) Immunology of psoriasis. Annu Rev Immunol 32:227-255

69. Cai Y, Shen X, Ding C, Qi C, Li K, Li X et al (2011) Pivotal role of dermal IL-17-producing $\gamma \delta \mathrm{T}$ cells in skin inflammation. Immunity 35(4):596-610

70. O'Brien RL, Born WK (2015) Dermal $\gamma \delta$ T cells - what have we learned? Cell Immunol 296(1):62-69

71. Zaba LC, Fuentes-Duculan J, Eungdamrong NJ, Johnson-Huang LM, Nograles KE, White TR et al (2010) Identification of TNFrelated apoptosis-inducing ligand and other molecules that distinguish inflammatory from resident dendritic cells in patients with psoriasis. J Allergy Clin Immunol 125(6):1261, 8.e9

72. Zaba LC, Krueger JG, Lowes MA (2009) Resident and "inflammatory" dendritic cells in human skin. J Invest Dermatol 129(2):302-308

73. Jacob SE, Nassiri M, Kerdel FA, Vincek V (2003) Simultaneous measurement of multiple $\mathrm{Th} 1$ and $\mathrm{Th} 2$ serum cytokines in psoriasis and correlation with disease severity. Mediators Inflamm 12(5):309-313

74. Arican O, Aral M, Sasmaz S, Ciragil P (2005) Serum levels of TNF-alpha, IFN-gamma, IL-6, IL-8, IL-12, IL-17, and IL-18 in patients with active psoriasis and correlation with disease severity. Mediators Inflamm 2005(5):273-279

75. Abanmi A, Al Harthi F, Al Agla R, Khan HA, Tariq M (2005) Serum levels of proinflammatory cytokines in psoriasis patients from Saudi Arabia. Int J Dermatol 44(1):82-83
76. Summers deLuca L, Gommerman JL (2012) Fine-tuning of dendritic cell biology by the TNF superfamily. Nat Rev Immunol 12(5):339-351

77. Eissner G, Kolch W, Scheurich P (2004) Ligands working as receptors: reverse signaling by members of the TNF superfamily enhance the plasticity of the immune system. Cytokine Growth Factor Rev 15(5):353-366

78. Gaur U, Aggarwal BB (2003) Regulation of proliferation, survival and apoptosis by members of the TNF superfamily. Biochem Pharmacol 66(8):1403-1408

79. Locksley RM, Killeen N, Lenardo MJ (2001) The TNF and TNF receptor superfamilies: integrating mammalian biology. Cell 104(4):487-501

80. Johnson-Huang LM, Suárez-Fariñas M, Pierson KC, FuentesDuculan J, Cueto I, Lentini T et al (2012) A single intradermal injection of IFN- $\gamma$ induces an inflammatory state in both nonlesional psoriatic and healthy skin. J Invest Dermatol 132(4): 1177-1187

81. Bowcock AM, Shannon W, Du F, Duncan J, Cao K, Aftergut K et al (2001) Insights into psoriasis and other inflammatory diseases from large-scale gene expression studies. Hum Mol Genet 10(17): 1793-1805

82. Harden JL, Johnson-Huang LM, Chamian MF, Lee E, Pearce T, Leonardi CL et al (2015) Humanized anti-IFN- $\gamma$ (HuZAF) in the treatment of psoriasis. J Allergy Clin Immunol 135(2):553-556

83. Sofen H, Smith S, Matheson RT, Leonardi CL, Calderon C, Brodmerkel C et al (2014) Guselkumab (an IL-23-specific mAb) demonstrates clinical and molecular response in patients with moderate-to-severe psoriasis. J Allergy Clin Immunol 133(4): 1032-1040

84. Kryczek I, Bruce AT, Gudjonsson JE, Johnston A, Aphale A, Vatan L et al (2008) Induction of IL-17+ T cell trafficking and development by IFN-gamma: mechanism and pathological relevance in psoriasis. J Immunol Baltim Md 1950 181(7):4733-41

85. Madonna S, Scarponi C, Sestito R, Pallotta S, Cavani A, Albanesi C (2010) The IFN-gamma-dependent suppressor of cytokine signaling 1 promoter activity is positively regulated by IFN regulatory factor- 1 and $\mathrm{Sp} 1$ but repressed by growth factor independence- $1 \mathrm{~b}$ and Krüppel-like factor-4, and it is dysregulated in psoriatic keratinocytes. J Immunol Baltim Md 1950 185(4): 2467-2481

86. Pestka S, Krause CD, Walter MR (2004) Interferons, interferonlike cytokines, and their receptors. Immunol Rev 202:8-32

87. La Mantia L, Capsoni F (2010) Psoriasis during interferon beta treatment for multiple sclerosis. Neurol Sci Off J Ital Neurol Soc Ital Soc Clin Neurophysiol 31(3):337-339

88. Downs AM, Dunnill MG (2000) Exacerbation of psoriasis by interferon-alpha therapy for hepatitis C. Clin Exp Dermatol 25(4):351-352

89. Tigalonova M, Bjerke JR, Gallati H, Degré M, Jablonska S, Majewski S et al (1994) Serum levels of interferons and TNFalpha are not correlated to psoriasis activity and therapy. Acta Derm Venereol Suppl (Stockh) 186:25-27

90. Van der Fits L, van der Wel LI, Laman JD, Prens EP, Verschuren MCM (2004) In psoriasis lesional skin the type I interferon signaling pathway is activated, whereas interferon-alpha sensitivity is unaltered. J Invest Dermatol 122(1):51-60

91. Eriksen KW, Lovato P, Skov L, Krejsgaard T, Kaltoft K, Geisler C et al (2005) Increased sensitivity to interferon-alpha in psoriatic $T$ cells. J Invest Dermatol 125(5):936-944

92. Gregorio J, Meller S, Conrad C, Di Nardo A, Homey B, Lauerma A et al (2010) Plasmacytoid dendritic cells sense skin injury and promote wound healing through type I interferons. J Exp Med 207(13):2921-2930

93. Santini SM, Lapenta C, Donati S, Spadaro F, Belardelli F, Ferrantini M (2011) Interferon- $\alpha$-conditioned human monocytes 
combine a Th1-orienting attitude with the induction of autologous Th17 responses: role of IL-23 and IL-12. PLoS One 6(2):e17364

94. Crouse J, Kalinke U, Oxenius A (2015) Regulation of antiviral T cell responses by type I interferons. Nat Rev Immunol 15(4):231242

95. Lee E, Trepicchio WL, Oestreicher JL, Pittman D, Wang F, Chamian $\mathrm{F}$ et al (2004) Increased expression of interleukin 23 p19 and p40 in lesional skin of patients with psoriasis vulgaris. $\mathbf{J}$ Exp Med 199(1):125-130

96. Gottlieb AB, Chamian F, Masud S, Cardinale I, Abello MV, Lowes MA et al (2005) TNF inhibition rapidly down-regulates multiple proinflammatory pathways in psoriasis plaques. J Immunol Baltim Md 1950 175(4):2721-9

97. Chamian F, Lowes MA, Lin S-L, Lee E, Kikuchi T, Gilleaudeau P et al (2005) Alefacept reduces infiltrating T cells, activated dendritic cells, and inflammatory genes in psoriasis vulgaris. Proc Natl Acad Sci U S A 102(6):2075-2080

98. Gandhi M, Alwawi E, Gordon KB (2010) Anti-p40 antibodies ustekinumab and briakinumab: blockade of interleukin-12 and interleukin-23 in the treatment of psoriasis. Semin Cutan Med Surg 29(1):48-52

99. Chan JR, Blumenschein W, Murphy E, Diveu C, Wiekowski M, Abbondanzo S et al (2006) IL-23 stimulates epidermal hyperplasia via TNF and IL-20R2-dependent mechanisms with implications for psoriasis pathogenesis. J Exp Med 203(12):2577-2587

100. Gaffen SL, Kramer JM, Yu JJ, Shen F (2006) The IL-17 cytokine family. Vitam Horm 74:255-282

101. Teunissen MB, Koomen CW, de Waal MR, Wierenga EA, Bos JD (1998) Interleukin-17 and interferon-gamma synergize in the enhancement of proinflammatory cytokine production by human keratinocytes. J Invest Dermatol 111(4):645-649

102. Krueger JG, Fretzin S, Suárez-Fariñas M, Haslett PA, Phipps KM, Cameron GS et al (2012) IL-17A is essential for cell activation and inflammatory gene circuits in subjects with psoriasis. J Allergy Clin Immunol 130(1):145-54.e9

103. Ding H-S, Yang J, Yang J, Ding J-W, Chen P, Zhu P (2012) Interleukin-17 contributes to cardiovascular diseases. Mol Biol Rep 39(7):7473-7478

104. Gisterå A, Robertson A-KL, Andersson J, Ketelhuth DFJ, Ovchinnikova O, Nilsson SK et al (2013) Transforming growth factor- $\beta$ signaling in $\mathrm{T}$ cells promotes stabilization of atherosclerotic plaques through an interleukin-17-dependent pathway. Sci Transl Med 5(196):196ra100

105. Lowes MA, Kikuchi T, Fuentes-Duculan J, Cardinale I, Zaba LC, Haider AS et al (2008) Psoriasis vulgaris lesions contain discrete populations of Th1 and Th17 T cells. J Invest Dermatol 128(5): 1207-1211

106. Suárez-Fariñas M, Lowes MA, Zaba LC, Krueger JG (2010) Evaluation of the psoriasis transcriptome across different studies by gene set enrichment analysis (GSEA). PLoS One 5(4):e10247

107. Papp KA, Leonardi C, Menter A, Ortonne J-P, Krueger JG, Kricorian G et al (2012) Brodalumab, an anti-interleukin-17receptor antibody for psoriasis. N Engl J Med 366(13):1181-1189

108. Papp KA, Reid C, Foley P, Sinclair R, Salinger DH, Williams G et al (2012) Anti-IL-17 receptor antibody AMG 827 leads to rapid clinical response in subjects with moderate to severe psoriasis: results from a phase I, randomized, placebo-controlled trial. J Invest Dermatol 132(10):2466-2469

109. Leonardi C, Matheson R, Zachariae C, Cameron G, Li L, EdsonHeredia E et al (2012) Anti-interleukin-17 monoclonal antibody ixekizumab in chronic plaque psoriasis. N Engl J Med 366(13): $1190-1199$

110. Gaffen SL (2009) Structure and signalling in the IL-17 receptor family. Nat Rev Immunol 9(8):556-567

111. Wang C, Wu L, Bulek K, Martin BN, Zepp JA, Kang Z et al (2013) The psoriasis-associated D10N variant of the adaptor
Act1 with impaired regulation by the molecular chaperone hsp90. Nat Immunol 14(1):72-81

112. Chiricozzi A, Nograles KE, Johnson-Huang LM, FuentesDuculan J, Cardinale I, Bonifacio KM et al (2014) IL-17 induces an expanded range of downstream genes in reconstituted human epidermis model. PLoS One 9(2):e90284

113. Goodman WA, Levine AD, Massari JV, Sugiyama H, McCormick TS, Cooper KD (2009) IL-6 signaling in psoriasis prevents immune suppression by regulatory T cells. J Immunol Baltim Md 1950 183(5):3170-6

114. Harper EG, Guo C, Rizzo H, Lillis JV, Kurtz SE, Skorcheva I et al (2009) Th17 cytokines stimulate CCL20 expression in keratinocytes in vitro and in vivo: implications for psoriasis pathogenesis. J Invest Dermatol 129(9):2175-2183

115. Chiricozzi A, Guttman-Yassky E, Suárez-Fariñas M, Nograles KE, Tian S, Cardinale I et al (2011) Integrative responses to IL17 and TNF- $\alpha$ in human keratinocytes account for key inflammatory pathogenic circuits in psoriasis. J Invest Dermatol 131(3): 677-687

116. Coimbra S, Oliveira H, Reis F, Belo L, Rocha S, Quintanilha A et al (2010) Interleukin (IL)-22, IL-17, IL-23, IL-8, vascular endothelial growth factor and tumour necrosis factor- $\alpha$ levels in patients with psoriasis before, during and after psoralen-ultraviolet A and narrowband ultraviolet B therapy. Br J Dermatol 163(6): 1282-1290

117. Boniface K, Lecron J-C, Bernard F-X, Dagregorio G, Guillet G, Nau F et al (2005) Keratinocytes as targets for interleukin-10related cytokines: a putative role in the pathogenesis of psoriasis. Eur Cytokine Netw 16(4):309-319

118. Wolk K, Witte E, Wallace E, Döcke W-D, Kunz S, Asadullah K et al (2006) IL-22 regulates the expression of genes responsible for antimicrobial defense, cellular differentiation, and mobility in keratinocytes: a potential role in psoriasis. Eur J Immunol 36(5): 1309-1323

119. Eyerich S, Eyerich K, Pennino D, Carbone T, Nasorri F, Pallotta S et al (2009) Th22 cells represent a distinct human T cell subset involved in epidermal immunity and remodeling. J Clin Invest 119(12):3573-3585

120. Liang SC, Tan X-Y, Luxenberg DP, Karim R, DunussiJoannopoulos K, Collins $\mathrm{M}$ et al (2006) Interleukin (IL)-22 and IL-17 are coexpressed by Th17 cells and cooperatively enhance expression of antimicrobial peptides. J Exp Med 203(10):22712279

121. Zheng Y, Danilenko DM, Valdez P, Kasman I, Eastham-Anderson J, Wu J et al (2007) Interleukin-22, a T(H)17 cytokine, mediates IL-23-induced dermal inflammation and acanthosis. Nature 445(7128):648-651

122. Antoniu SA (2012) Discontinued drugs 2011: pulmonary, allergy, gastrointestinal and arthritis. Expert Opin Investig Drugs 21(11): $1607-1618$

123. Asumalahti K, Ameen M, Suomela S, Hagforsen E, Michaëlsson G, Evans J et al (2003) Genetic analysis of PSORS1 distinguishes guttate psoriasis and palmoplantar pustulosis. J Invest Dermatol 120(4):627-632

124. Robinson A, Van Voorhees AS, Hsu S, Korman NJ, Lebwohl MG, Bebo BF et al (2012) Treatment of pustular psoriasis: from the Medical Board of the National Psoriasis Foundation. J Am Acad Dermatol 67(2):279-288

125. Saggini A, Chimenti S, Chiricozzi A (2014) IL-6 as a druggable target in psoriasis: focus on pustular variants. J Immunol Res 2014:964069

126. Onoufriadis A, Simpson MA, Pink AE, Di Meglio P, Smith CH, Pullabhatla V et al (2011) Mutations in IL36RN/IL1F5 are associated with the severe episodic inflammatory skin disease known as generalized pustular psoriasis. Am J Hum Genet 89(3):432-437 
127. Marrakchi S, Guigue P, Renshaw BR, Puel A, Pei X-Y, Fraitag S et al (2011) Interleukin-36-receptor antagonist deficiency and generalized pustular psoriasis. N Engl J Med 365(7):620-628

128. Hussain S, Berki DM, Choon S-E, Burden AD, Allen MH, Arostegui JI et al (2015) IL36RN mutations define a severe autoinflammatory phenotype of generalized pustular psoriasis. J Allergy Clin Immunol 135(4):1067-70.e9

129. Berki DM, Mahil SK, Burden AD, Trembath RC, Smith $\mathrm{CH}$, Capon F et al (2014) Loss of IL36RN function does not confer susceptibility to psoriasis vulgaris. J Invest Dermatol 134(1):271273

130. Towne JE, Garka KE, Renshaw BR, Virca GD, Sims JE (2004) Interleukin (IL)-1F6, IL-1F8, and IL-1F9 signal through IL-1Rrp2 and IL-1RAcP to activate the pathway leading to NF-kappaB and MAPKs. J Biol Chem 279(14):13677-13688

131. Towne JE, Sims JE (2012) IL-36 in psoriasis. Curr Opin Pharmacol 12(4):486-490

132. Setta-Kaffetzi N, Simpson MA, Navarini AA, Patel VM, Lu H-C, Allen MH et al (2014) AP1S3 mutations are associated with pustular psoriasis and impaired Toll-like receptor 3 trafficking. Am J Hum Genet 94(5):790-797

133. Guarda G, Braun M, Staehli F, Tardivel A, Mattmann C, Förster I et al (2011) Type I interferon inhibits interleukin-1 production and inflammasome activation. Immunity 34(2):213-223

134. Mössner R, Frambach Y, Wilsmann-Theis D, Löhr S, Jacobi A, Weyergraf A et al (2015) Palmoplantar pustular psoriasis is associated with missense variants in CARD14, but not with loss-offunction mutations in IL36RN in European Patients. J Invest Dermatol 135(10):2538-2541

135. Berki DM, Liu L, Choon S-E, David Burden A, Griffiths CEM, Navarini AA et al (2015) Activating CARD14 mutations are associated with generalized pustular psoriasis but rarely account for familial recurrence in psoriasis vulgaris. J Invest Dermatol 23

136. Sugiura K, Muto M, Akiyama M (2014) CARD14 c.526G $>$ C (p.Asp176His) is a significant risk factor for generalized pustular psoriasis with psoriasis vulgaris in the Japanese cohort. J Invest Dermatol 134(6):1755-1757

137. Scudiero I, Zotti T, Ferravante A, Vessichelli M, Vito P, Stilo R (2011) Alternative splicing of CARMA2/CARD14 transcripts generates protein variants with differential effect on NF- $\mathrm{KB}$ activation and endoplasmic reticulum stress-induced cell death. J Cell Physiol 226(12):3121-3131

138. Jordan CT, Cao L, Roberson EDO, Pierson KC, Yang C-F, Joyce $\mathrm{CE}$ et al (2012) PSORS2 is due to mutations in CARD14. Am J Hum Genet 90(5):784-795

139. Zaba LC, Suárez-Fariñas M, Fuentes-Duculan J, Nograles KE, Guttman-Yassky E, Cardinale I, et al. Effective treatment of psoriasis with etanercept is linked to suppression of IL-17 signaling, not immediate response TNF genes. J Allergy Clin Immunol. 2009 Nov;124(5):1022-1010.e1-395.

140. Mankia S, Peters JE, Kang S, Moore S, Ehrenstein MR (2011) Tuberculosis and anti-TNF treatment: experience of a central London hospital. Clin Rheumatol 30(3):399-401

141. Mariette X, Tubach F, Bagheri H, Bardet M, Berthelot JM, Gaudin $P$ et al (2010) Lymphoma in patients treated with anti-TNF: results of the 3-year prospective French RATIO registry. Ann Rheum Dis 69(2):400-408

142. Lakatos PL, Miheller P (2010) Is there an increased risk of lymphoma and malignancies under anti-TNF therapy in IBD? Curr Drug Targets 11(2):179-186

143. Mahil SK, Andrews TC, Brierley C, Barker JN, Smith CH (2013) Demyelination during tumour necrosis factor antagonist therapy for psoriasis: a case report and review of the literature. J Dermatol Treat 24(1):38-49

144. Gregory AP, Dendrou CA, Attfield KE, Haghikia A, Xifara DK, Butter F et al (2012) TNF receptor 1 genetic risk mirrors outcome of anti-TNF therapy in multiple sclerosis. Nature 488(7412):508511

145. Joyau C, Veyrac G, Dixneuf V, Jolliet P (2012) Anti-tumour necrosis factor alpha therapy and increased risk of de novo psoriasis: is it really a paradoxical side effect? Clin Exp Rheumatol 30(5): 700-706

146. Papp KA, Langley RG, Lebwohl M, Krueger GG, Szapary P, Yeilding $\mathrm{N}$ et al (2008) Efficacy and safety of ustekinumab, a human interleukin-12/23 monoclonal antibody, in patients with psoriasis: 52-week results from a randomised, double-blind, placebo-controlled trial (PHOENIX 2). Lancet 371(9625):16751684

147. Leonardi CL, Kimball AB, Papp KA, Yeilding N, Guzzo C, Wang Y et al (2008) Efficacy and safety of ustekinumab, a human interleukin-12/23 monoclonal antibody, in patients with psoriasis: 76-week results from a randomised, double-blind, placebo-controlled trial (PHOENIX 1). Lancet 371(9625):1665-1674

148. Griffiths CEM, Strober BE, van de Kerkhof P, Ho V, Fidelus-Gort $\mathrm{R}$, Yeilding $\mathrm{N}$ et al (2010) Comparison of ustekinumab and etanercept for moderate-to-severe psoriasis. N Engl J Med 362(2):118-128

149. Daudén E, Santiago-et-Sánchez-Mateos D, Sotomayor-López E, García-Díez A (2010) Ustekinumab: effective in a patient with severe recalcitrant generalized pustular psoriasis. Br J Dermatol 163(6):1346-1347

150. Morales-Múnera C, Vilarrasa E, Puig L (2013) Efficacy of ustekinumab in refractory palmoplantar pustular psoriasis. Br J Dermatol 168(4):820-824

151. Saunier J, Debarbieux S, Jullien D, Garnier L, Dalle S, Thomas L (2014) Acrodermatitis continua of Hallopeau treated successfully with ustekinumab and acitretin after failure of tumour necrosis factor blockade and anakinra. Dermatol Basel Switz

152. Bertelsen T, Kragballe K, Johansen C, Iversen L (2014) Efficacy of ustekinumab in palmoplantar pustulosis and palmoplantar pustular psoriasis. Int J Dermatol 53(10):e464-e466

153. Kofoed K, Skov L, Zachariae C (2015) New drugs and treatment targets in psoriasis. Acta Derm Venereol 95(2):133-139

154. Papp KA, Langley RG, Sigurgeirsson B, Abe M, Baker DR, Konno P et al (2013) Efficacy and safety of secukinumab in the treatment of moderate-to-severe plaque psoriasis: a randomized, double-blind, placebo-controlled phase II dose-ranging study. Br J Dermatol 168(2):412-421

155. Langley RG, Elewski BE, Lebwohl M, Reich K, Griffiths CEM, Papp K et al (2014) Secukinumab in plaque psoriasis - results of two phase 3 trials. N Engl J Med 371(4):326-338

156. Hueber W, Patel DD, Dryja T, Wright AM, Koroleva I, Bruin G et al (2010) Effects of AIN457, a fully human antibody to interleukin-17A, on psoriasis, rheumatoid arthritis, and uveitis. Sci Transl Med 2(52):52-72

157. Lebwohl M, Strober B, Menter A, Gordon K, Weglowska J, Puig L et al (2015) Phase 3 studies comparing brodalumab with ustekinumab in psoriasis. N Engl J Med 373(14):1318-1328

158. Schafer $P$ (2012) Apremilast mechanism of action and application to psoriasis and psoriatic arthritis. Biochem Pharmacol 83(12): $1583-1590$

159. Papp K, Cather JC, Rosoph L, Sofen H, Langley RG, Matheson RT et al (2012) Efficacy of apremilast in the treatment of moderate to severe psoriasis: a randomised controlled trial. Lancet 380(9843):738-746

160. Papp KA, Menter A, Strober B, Langley RG, Buonanno M, Wolk $R$ et al (2012) Efficacy and safety of tofacitinib, an oral Janus kinase inhibitor, in the treatment of psoriasis: a Phase $2 \mathrm{~b}$ randomized placebo-controlled dose-ranging study. Br J Dermatol 167(3): 668-677 
161. Van de Kerkhof PCM (2015) An update on topical therapies for mild-moderate psoriasis. Dermatol Clin 33(1):73-77

162. Ports WC, Khan S, Lan S, Lamba M, Bolduc C, Bissonnette R et al (2013) A randomized phase 2a efficacy and safety trial of the topical Janus kinase inhibitor tofacitinib in the treatment of chronic plaque psoriasis. Br J Dermatol 169(1):137-145

163. Punwani N, Scherle P, Flores R, Shi J, Liang J, Yeleswaram S et al (2012) Preliminary clinical activity of a topical JAK1/2 inhibitor in the treatment of psoriasis. J Am Acad Dermatol 67(4):658-664

164. Fishman P, Bar-Yehuda S, Liang BT, Jacobson KA (2012) Pharmacological and therapeutic effects of A3 adenosine receptor agonists. Drug Discov Today 17(7-8):359-366

165. David M, Akerman L, Ziv M, Kadurina M, Gospodinov D, Pavlotsky F et al (2012) Treatment of plaque-type psoriasis with oral CF101: data from an exploratory randomized phase 2 clinical trial. J Eur Acad Dermatol Venereol JEADV 26(3):361-367

166. Viguier M, Guigue P, Pagès C, Smahi A, Bachelez H (2010) Successful treatment of generalized pustular psoriasis with the interleukin-1-receptor antagonist Anakinra: lack of correlation with IL1RN mutations. Ann Intern Med 153(1):66-67

167. Hüffmeier U, Wätzold M, Mohr J, Schön MP, Mössner R (2014) Successful therapy with anakinra in a patient with generalized pustular psoriasis carrying IL36RN mutations. Br J Dermatol 170(1):202-204
168. Lutz V, Lipsker D (2012) Acitretin- and tumor necrosis factor inhibitor-resistant acrodermatitis continua of hallopeau responsive to the interleukin 1 receptor antagonist anakinra. Arch Dermatol 148(3):297-299

169. Tauber M, Viguier M, Le Gall C, Smahi A, Bachelez H (2014) Is it relevant to use an interleukin-1-inhibiting strategy for the treatment of patients with deficiency of interleukin-36 receptor antagonist? Br J Dermatol 170(5): 1198-1199

170. Hussain S, Berki DM, Choon S-E, Burden AD, Allen MH, Arostegui JI, et al. (2014) IL36RN mutations define a severe autoinflammatory phenotype of generalized pustular psoriasis. J Allergy Clin Immunol

171. Tauber M, Viguier M, Alimova E, Petit A, Lioté F, Smahi A et al (2014) Partial clinical response to anakinra in severe palmoplantar pustular psoriasis. Br J Dermatol 171(3):646-649

172. Seminara NM, Gelfand JM (2010) Assessing long-term drug safety: lessons (re) learned from raptiva. Semin Cutan Med Surg 29(1):16-19

173. Radtke MA, Augustin M (2014) Biosimilars in psoriasis: what can we expect? J Dtsch Dermatol Ges J Ger Soc Dermatol JDDG 12(4):306-312 